\title{
تقويم مهارات التحدث باللغة الإنجليزية لدى طالبات الصف الأول الثانوي بمنطقة القصيم
}

\author{
بلوساذة / تهاني ابراهيم السلوع \\ قسم المناهج وطرق التدريس \\ كلية التربية- جامعة القصييم
}

\author{
د / وليد بن ابراهيم علي العبيكي \\ قسم المناهج وطرق التدريس \\ كلية التربية- جامعة القصيم
}

هدفت الدراسة إلى تقويم مهارات التحدث باللغة الإنجليزية لدى طالبات الصف الأول الثانوي

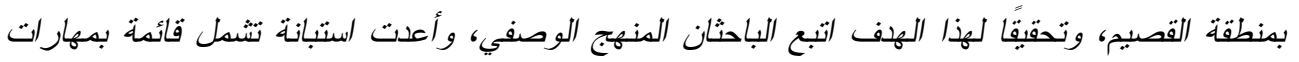

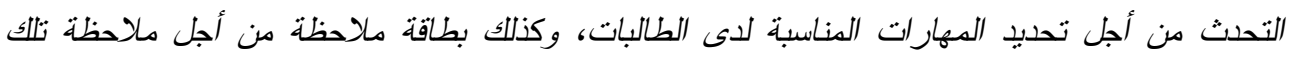

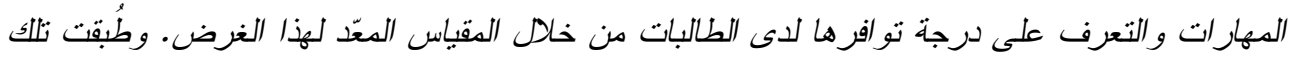

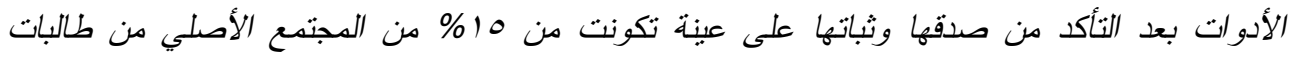

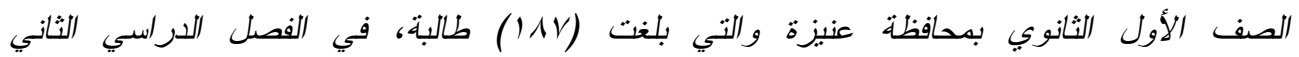
$\rightarrow 1 \leqslant r q / 1 \leqslant r_{0}$

وتوصلت الدراسة إلى إعداد قائمة بمهارات التحدث باللغة الإنجليزية مكونة من ثلاث مهارات

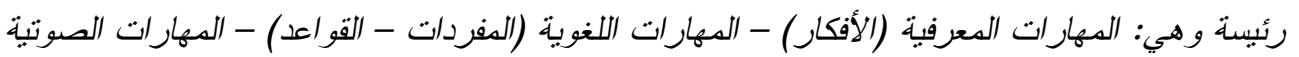
(النطق - الطلاقة)، واشتملت تلك المهارات على مهار ات فرعية أخرى تضمنتها القائمة.

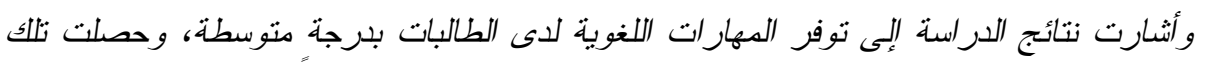

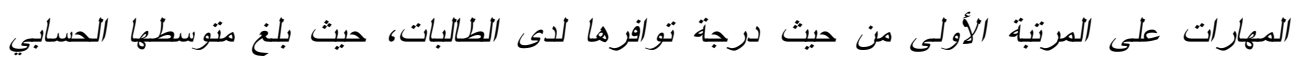

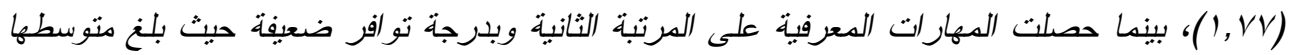

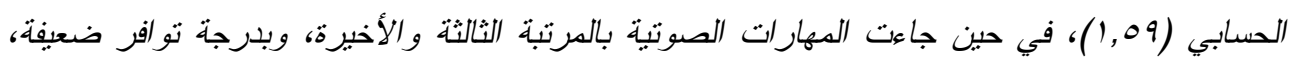

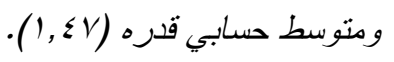
وفي ضوء ما أسفرت عنه نتائج الدراسة، قدم الباحثان عدداً من التوصيات و المقترحات المرتبطة بهذه النتائج.

\section{Abstract:}

The present study aimed at evaluating English language speaking skills of secondary first grade female students in Al-Qassim region. In order to attain this aim, the study employed the descriptive approach. Data collection was carried out by means of a questionnaire including an inventory of speaking skills in order to 
determine the appropriate skills among students, in addition to an observation sheet to observe these skills and to identify to what extent they are available at the students by the scale developed for this purpose.

After verifying the validity and reliability of the tools, they were administered on a sample consisting of (187) female students who represent $15 \%$ of the population (these are secondary first grade female students at Onaizah Governate) in the second semester of the academic year 1435/1436 AH.

The study has developed an inventory of English language speaking skills involving three main skills, namely: cognitive skills (ideas), linguistic skills (vocabulary- structures), and phonological skills (pronunciation, fluency), in addition to other sub-skills included in the inventory.

The results of the study pointed out the average availability of linguistic skills among students as they came first among the skills students possess with a mean of (1.77). while the students had poor cognitive skills that came second with a mean of (1.59), and phonological skills came in the third place with a mean of (1.47).

According to the previous results, the researcher suggested a number of recommendations associated with the study consequences.

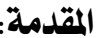

$$
\begin{aligned}
& \text { و على الرغم مــن أهميــة مهـــار ات } \\
& \text { التحدث ،وما تشهـه مناهج اللغة الإنجليزيــة }
\end{aligned}
$$

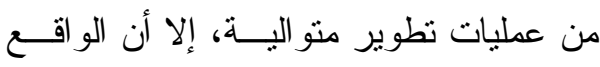

$$
\begin{aligned}
& \text { يثير إلى وجود أوجه قــصور فـي تمكـن } \\
& \text { الطالبات من المهـــار ات الــثفوية خاصـــة }
\end{aligned}
$$

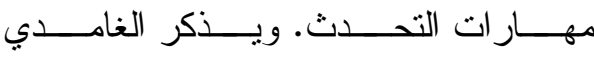

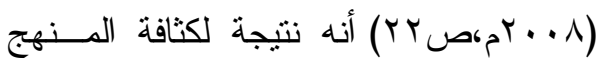

$$
\begin{aligned}
& \text { من جهة و عدم تلقي المعلمين لتدريب كــاف } \\
& \text { من جهة أخرى، بالإضـافة إلى إثقال كاهــل } \\
& \text { معلم اللغة الإنجليزية بكثير من الواجبات إلى } \\
& \text { جانب واجبه الأصلي وهو تتمية المهـار ات } \\
& \text { اللغوية في وقـت ضيق، أصــبحت هنــاك } \\
& \text { مؤشر ات تذل على ضعف اكتساب التلاميــذ }
\end{aligned}
$$

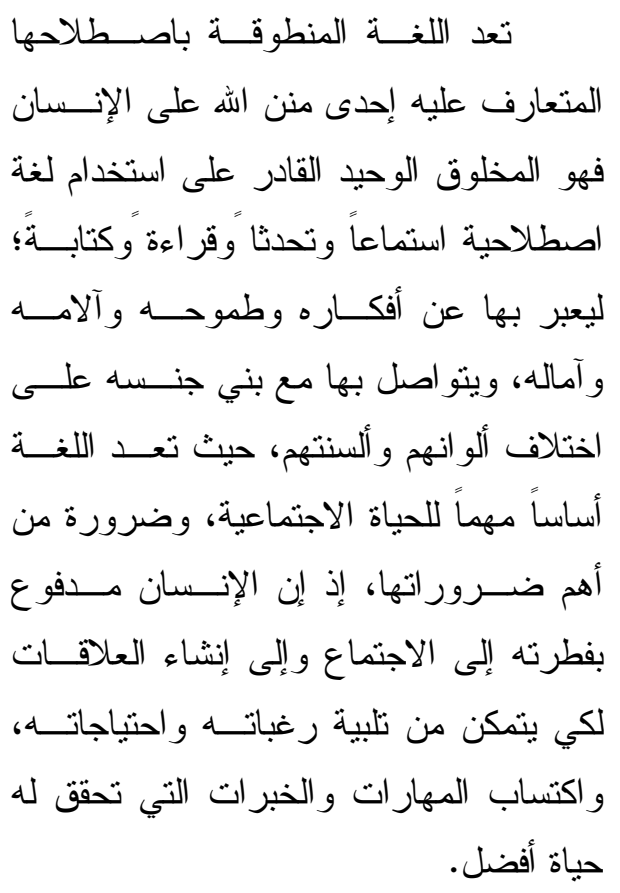


العربية والأجنبية لتدريس اللغة الإنجليزيــة إلى جانب الخريجين السعوديين مــن أقـسام اللغة الإنجليزية في كليات التزبيــة والآداب

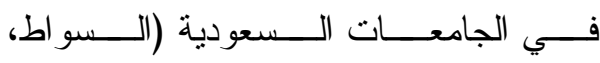

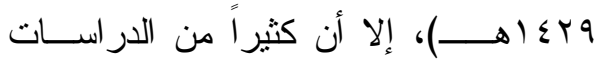

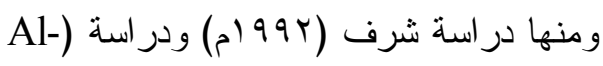

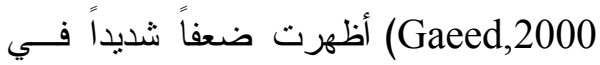

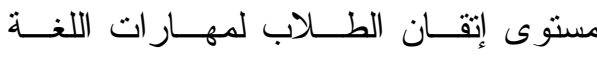
الأساسية خصوصناً مهارة التحدث.

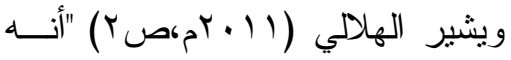

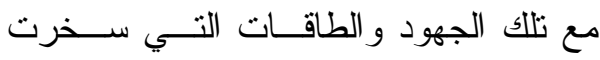
لتطوير تعلـيم اللغـــة الإنجليزيــة واتقــان مهار اتها، إلا أن مهارتي الاستماع و التحدث لا تحظيا بالنصيب الأوفــر مــن الاهتمــام و العناية، لذا فإنه مع تللك المدة الني يقـضيها الطلاب في دراسة اللغة فإنهم ينهون الـسنة

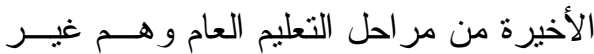

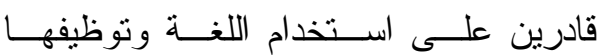
التوظيف الأمنل في مو اقـف حيـــة خــارج الصف الدراسي، وأن غالبية ما يكتسبونه لا لا هولية يتعدى بعض المفردات و القو اعـــــ لاجتيــاز الاختبار ات التحصيلية للمقرر". وبناءً على ما سبق، و واســتناداً علــى

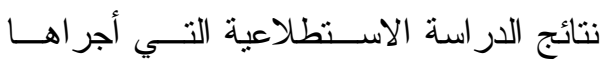

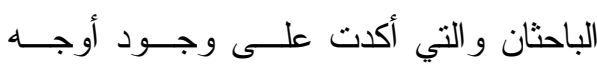

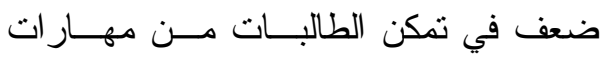
التحدث، وفي ضوء ما أظهرته الدراســات

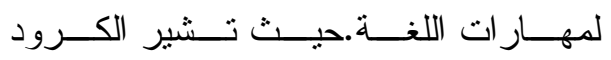

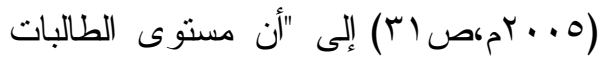

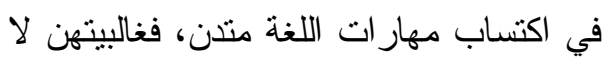
يستطعن القراءة، و البعض الآخر لا يستطعن التحدث بطلاقة، وبعضهن لا يحسن الكتابة". وقد أسفرت العديد من نتائج الدراسات عن تدني مهار ات الاستماع و التحدث لــدى لــ الطلاب في مختلف المراحل التعليمية، الأمر

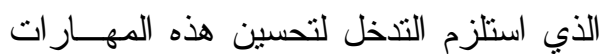

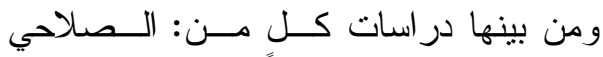

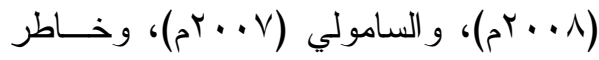

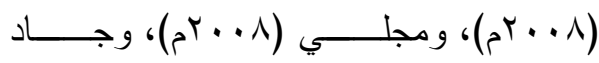

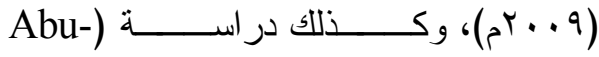
(AL-Alili,2009)و) (Ghararah, 1992 و (AL-Subhi,1992). بناءً على ما تقدم تبرز مشكلة الدر اسة

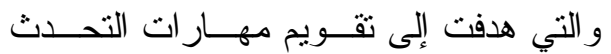
باللغة الإنجليزية في محاولة للوصول إلى ما يعزز الايجابيات الموجودة والسعي إلى تقديم

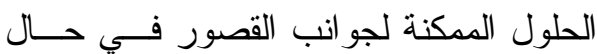
ظهور ها.

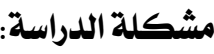

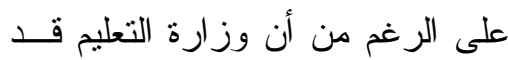

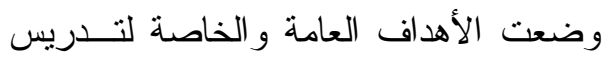

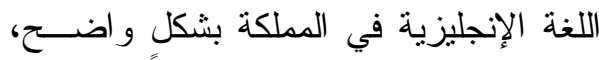

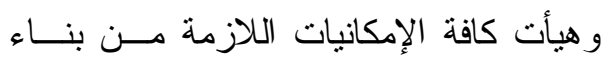

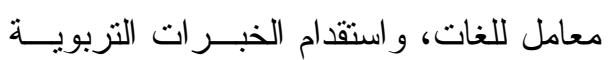




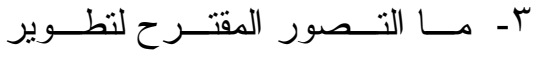

$$
\begin{aligned}
& \text { التربوية الحديثة، فان مشكلة الدراسة الحالية } \\
& \text { مهار ات التحــدث لـدى طالبــات } \\
& \text { الصف الأول الثانوي؟ } \\
& \text { أهداف الدراسة: هدفت الاراسة إلى: }
\end{aligned}
$$

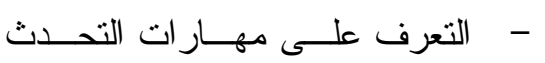

$$
\begin{aligned}
& \text { المناسبة لطالبــات الـــف الأول } \\
& \text { الثانوي. }
\end{aligned}
$$

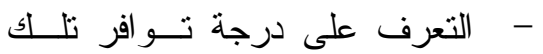

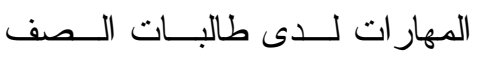

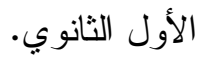

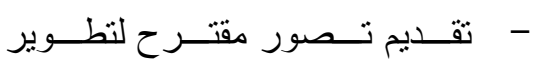

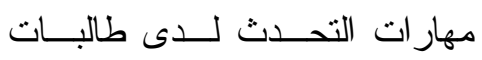

$$
\begin{aligned}
& \text { الصف الأول الثانوي. } \\
& \text { أهمية الدراسة: تمثلت أهمية الدراســة مــن } \\
& \text { أ- ما درجة نو افر المهارات المعرفية لالل الجوانب التالية: }
\end{aligned}
$$

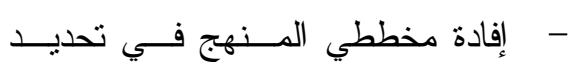

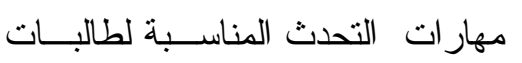

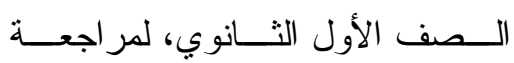

$$
\begin{aligned}
& \text { محتوى المنهج في ضو ذء ذللك. }
\end{aligned}
$$

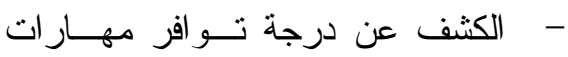

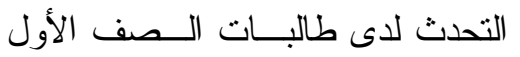

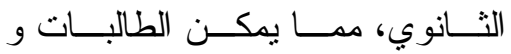

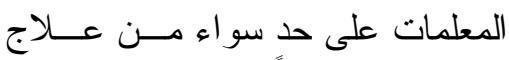

$$
\begin{aligned}
& \text { أوجه القصور لديهن. } \\
& \text { اللازمة للتحدث باللغة الإنجليزية }
\end{aligned}
$$

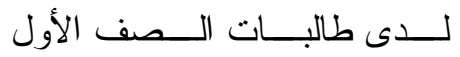

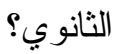

$$
\begin{aligned}
& \text { ب- ما درجة نو افر المهارات اللغوية } \\
& \text { اللازمة للتحدث باللغة الإنجليزية }
\end{aligned}
$$

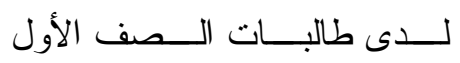

$$
\begin{aligned}
& \text { الثانوي؟ } \\
& \text { ج- مــا درجــة تــــوافر المهــار ات } \\
& \text { الصوتية اللازمة للتحدث باللغــة }
\end{aligned}
$$

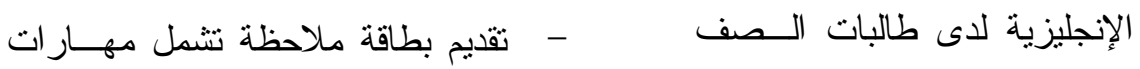

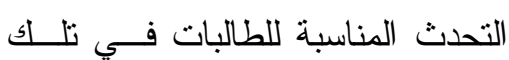

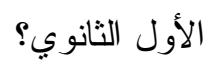


تشخيص مدى تمكــن الطالبــات لمهـــار ات التحدث باللغة الإنجليزية من خلال الدرجــة التى يحصلن عليها فــي بطاقــة الملاحظـــة

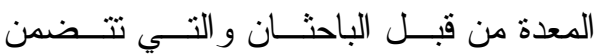
المهار ات المستهدف تقويمها، وتقديم تصور مقترح لعلاج أوجه الضعف.

Speaking مهــارات التحــــــ

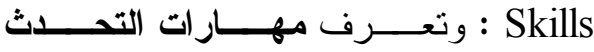
Speaking Skills وفي ضوء ما سبق بأنهــــا : الأداء اللغـــوي

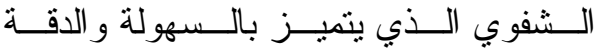
و الوضوح في اختيار الطالبات للأفكار الجيدة

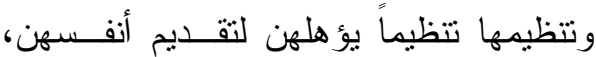

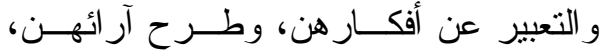
و القدرة على اختيــار المفــردات المناســبة

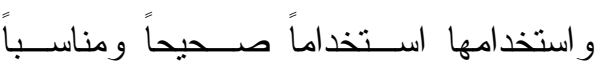
للموقف و وفق متطلبــات الــسؤ البونطقها نطقاً صحيحاً مسترسلاً.

اللدراسات السابقة: الار اسات العربية:

هدفت دراسة آل ريبة (V . . r م) إلى

تقويم أساليب تــدريس مهــار ات الاتــصال الشفوي (الاستماع - التحدث) لدى معلمــي اللغة الإنجليزية بالمرحلة الثانويــة بمنطقـة عسير، واتبع الباحــث المــنهج الوصــفي،

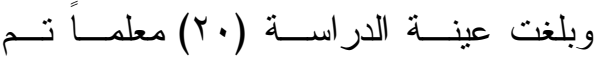
اختيار هم عشوائياً من عشر مدارس بمدينتي
المرحلة على درجــة مقبولــة مــن الصدق و الثبات، و إمكانية الاســتفادة منها أو تطوير ها مــن قبـــل بــاحثين

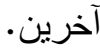
- - - إفادة المسؤولين وصناع القــرار فــي

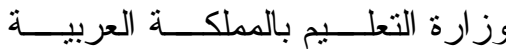
السعودية من نتائج هذه الدر اسـة مــن أجل العمل على تذعيم نقــاط القـــوة ومعالجة نقاط الضعف الني قد نظهر في أساليب تقويم مهارت التحدث. حدود الدراسة: اقتصرث الدراسة على: - الحدود الموضوعية :على الرغم من ارنباط مهـــارة التحـــث بالمهـــار ات اللغويــــة الأخـــرى، إلا أن الدر اســـة الحالية اقتــصرت فــي موضـــوعها و هدفها على تقويم مهار ات التحــدث لاى طالبات الصف الأول الثانوي. - - الحدود المكانية :طُبقت هذه الدراسة في مدارس المرحلة الثانوية للبنــات التابعة لإدارة التعليم بمحافظة عنيزة. - الحدود الزمانية. تم إجر اء الدراســة في الفصل الدر اســـي التــاني للعـــام

$$
\text { . } 1 \leqslant \pi / 1 \leq r 0
$$

\section{مصطلحات اللدراسة:}

التقويم Evaluation : ويُقصد بتقويم

مهار ات التحدث إجرائياً في هذه الدر اســـة: 
التجريبي، وبلغت عينة الدر اسة (ro) طالبــا قسمو المجمو عتين تجريبية وضابطة، حيــث درست المجموعة التجريبية المكونــة مــن طالباً باستخدام الأنشطة الترفيهية لمدة (rV) ستة أسـابيع، في حـين درســت المجموعــة الضابطة المكونة مــن (Yo) طالبــاً بــدون استخدام الأنشطة الترفيهية، وقد طبق الباحث كأداة للار اسة اختبار اً في الاستماع و آخر في التحدث، ومن أهم نتائج الدراسة ذات الصلة بموضوع الدر اسة الحالية وجود فــرق دال

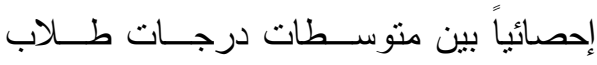
المجمو عتين التجريبية و الضابطة في تطبيــق اختبار التحــدث البعـــدي لــصالح طـلاب المجمو عة التجريبية.

وركــزت در اســــة كمــــال الـــــين

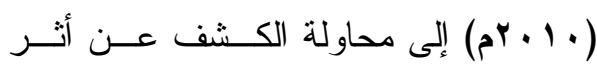
برنامج إثزائي قائم على التعليم التمركز حول الطالب في تتمية بعض مهار ات الاســنماع

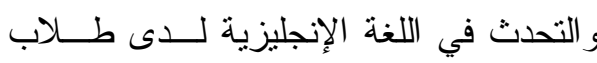
الصف الأول الثــانوي، و اســتخدم الباحــثـ إثـ المنهج شبه التجريبي، وبلغت عينة الدر اســة ( • 1 (1) طالباً قسمو ا بالتساوي لمجمــوعتين

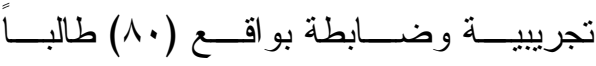
للمجموعة التجريبية و (•^) طالباً للمجموعة الضـابطة ولتحقيق أهداف الدر اســـة صـــمم الباحث اختبار اً قبلياً وبعــدياً فــي مهـــار ات الاستماع و آخــر فــي مهـــار ات التــــدث،
أبها وخمــيس مــشيط. و اســتخدم الباحــث الاستبانة و بطاقة الملاحظة وكذلك المقابلات للتعرف على المعوقات التي تواجه معلم اللغة الإنجليزية في ممارســة أســاليب تــدريس

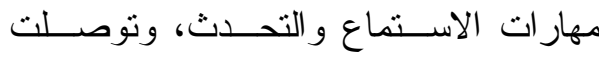
الار اسة على عدد من النتائج أهمها: تــدني ممارسة معلمي اللغة الإنجليزيـــة لأســاليب تدريس مهار ات الاســـماع و التحــدث، وأن معظم الأساليب التـي بــستخدمونها كانــــ أساليب تقليدية مكررة تعتمد علـى الــشرح و الإلقاء في تدريس القو اعد و المفردات وتخلو

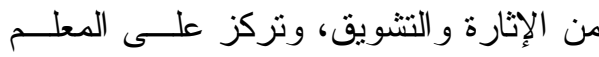

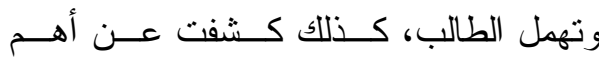
المعوقات التي تقف حـــائلاُ أمـــام ممارســــة المعلمين للأساليب الحديثــة فــي تــدريس مهار ات الاستماع و التحدث، وقــد أوصــى الباحث في نهاية در استه بـــإجر اء در اســـات تجريبية لاختبار فعالية التــدريس باســتخدام أسلوب القصة و الألعاب اللغوية فــي نتميــة مهـــار ات الاتــصـال الــثنفوي (الاســـتماع

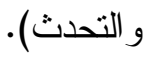

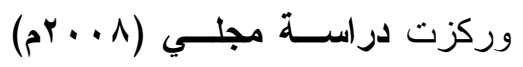

على محاولة الكثف عن أثز استخدام أنشطة قائمة على الترفيه في تتمية بعض مهـــار ات

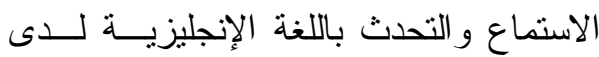

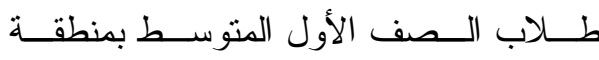
جاز ان، و اســتخدم الباحــث المــنهج شــبه 
كذلك أسفرت عن وجود فرق دال إحــصائياً بين الذكور و الإناث في مهار ات التحدث التي

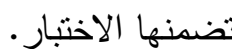

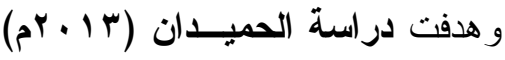

إلى معرفة مدى فاعلية المهمات التعليمية في تطوير مهارة التحدث لدى طلاب مقرر اللغة الإنجليزية العامة في الكلية التقنيــة بمدينـــة

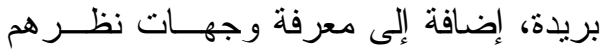
تجاه استخدام المهمــات فــي تعلـــم مهــارة

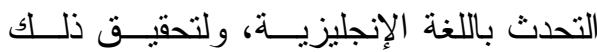
استخدم الباحث المنهج شبة التجريبي وقـام ولتهي باختيار عينة الدراسة بشكل عشوائي والبالغ

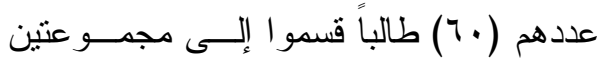
أحدهما تجريبية و الأخرى ضابطة إذ قـدمت إنـان

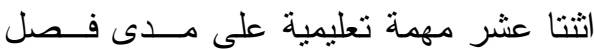
تدريبي كامل للمجموعة التجرييية، ولم تقــدم مهمات تعليمية لأفر اد المجموعة الــضـابطة، كماكة كما أجريت اختبار ات تحصيلية للمجموعنين،

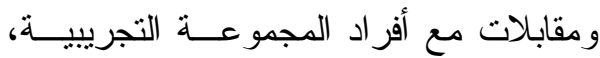

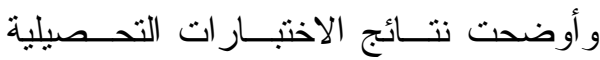

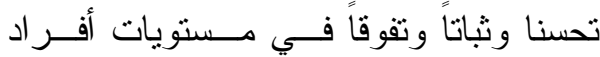

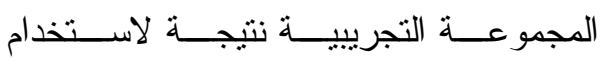
المهمات، كما أوضحت نتائج المقابلات التي لئليات أجريت معهم قنــاعتهم بإمكانيــة اســتخدام

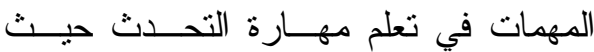
تطورت مستوياتهم في هذه المهــارة وزادت

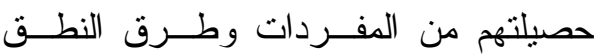
الصحيحة لمفردات اللغة وتطورت قــدر اتهم

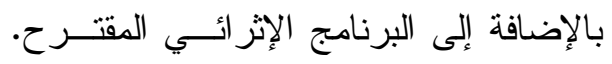
وكثفت نتائج الدراسة علــى أن البرنــامج الإنس

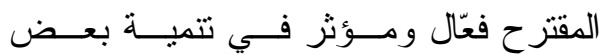

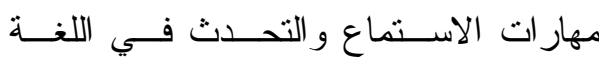
الإنجليزية لدى طلاب الصف الأول الثانوي

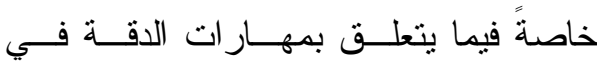

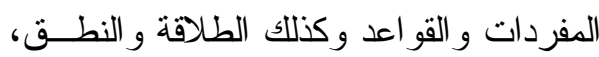

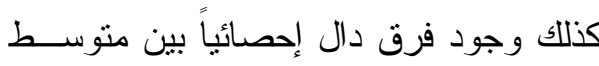
درجات المجموعتين التجريبية و الضابطة في تطبيق اختبار الاستماع و التحــدث البعـدي لصالح المجمو عة التجريبية. وركزت دراســة ســليمان، زينــات (11 +ra) على البحث عن فاعلية برنــامج مقترح قائم على المدخل التو اصلي في تتمية

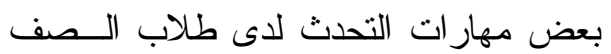
الأول الإعدادي التي تشمل مهار ات التفاعـلـل

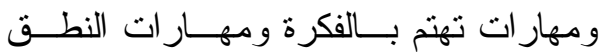
و الطلاقة، و استخدم الباحثان المـــهج شـــــه التجريبي، وبلغت عينة الدر اسة (7^) طالبــاً قسمو ا إلى مجمو عتين تجريبية وضابطة،وفي

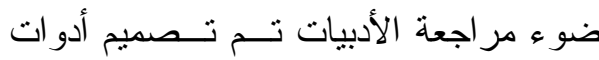

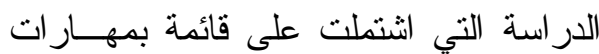

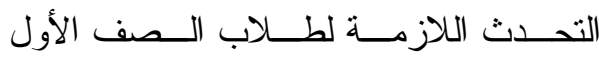

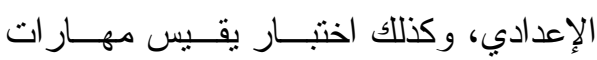
التحدث و البرنامج المقتر ح. و أسفرت نتــائج

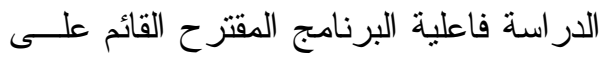
المدخل التو اصلي في تتمية بعض مهــار ات

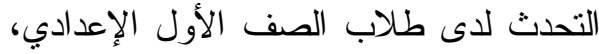


تتمية وتطوير مهارات التحدث لدى الطلاب،

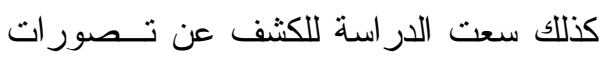

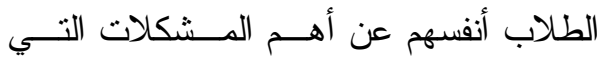

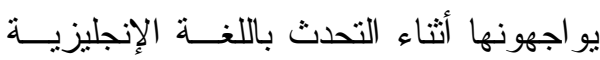
و استخدم الباحثان المنهج الوصفي، ولتحقيق أهداف الدراسة أُجريت العديد من المقابلات

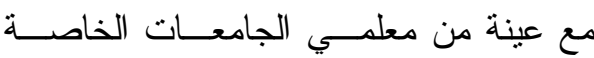

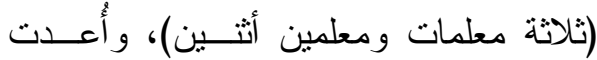

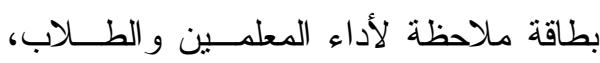
وكذلك تحليل لعدد من الوثائق منهـــا أســـئلة

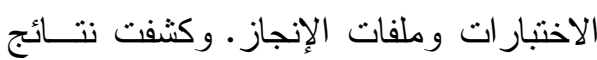

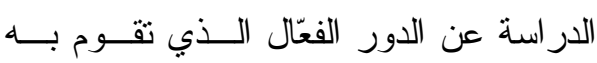

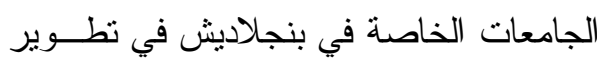

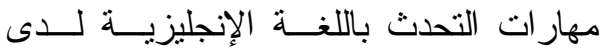
طلابها حيث بمتاز طلاب الجامعات الخاصة بات الإن بكفاءة أكبر مـن (Private Universities)

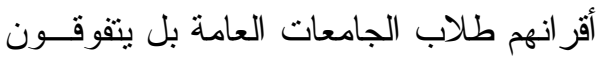

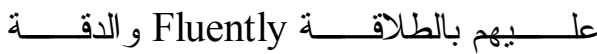
Accuracy

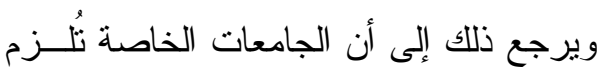

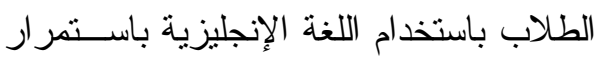

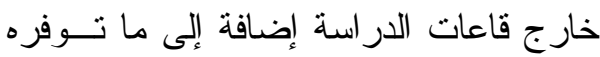

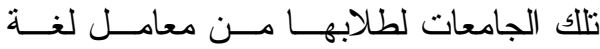

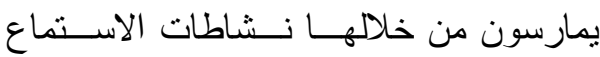

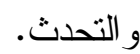

وهـدفت دراســة ) Rapley, D. J.

2008) إلى التعرف على رأي معلمي اللغـــة

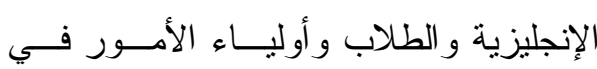

في القو اعد النحوية للانجليزية، وكذلك فـي الطلاقة و الدقة أثثاء ممارسة التحدث باللغــــة الإنجليزية.

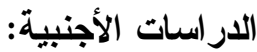

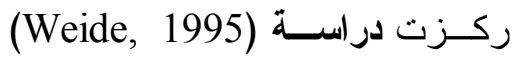

على تحسين مهار ات التحـدث و الاتـــال و الطلاقة لدى تلاميذ الصفين الثاني و الثالـــث

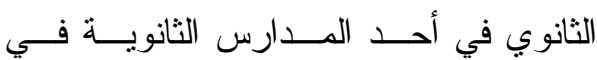

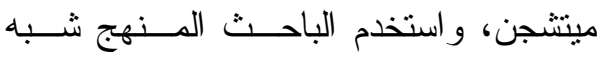
التجريبي، وبلغت عينة الدر اسة (ب و) تلميذاً قسموا إلى مجمو عتنن تجريبية تكونت مسنـ

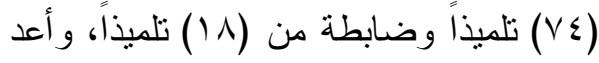
الباحث برنامجاً مقترحاً لتحسين الطلاقة لدى

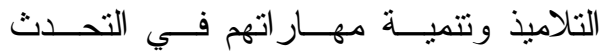
والاتصلال، و أظهرت نتائج الدراسة تحسـسناً ملحوظاً في أداء التلاميذ لمهار وات التحــدث و الاتصال من حيث الطلاقة و السلاسة فــي في الحديث، بالإضافة إلى إدر الك معظم المعلمين

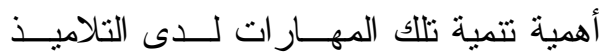

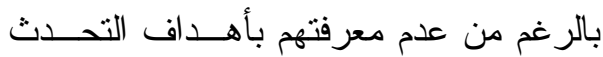

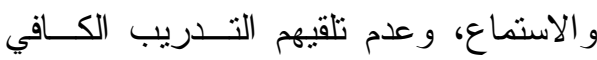
لتدريس الاتصال الشفوي بمهارنيه.

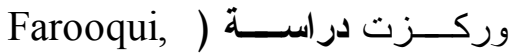
(Sabrin, 2006 لدى طلاب الجامعات الخاصة في بــنجلادش كما هدفت للكثف عن تصور ات المعلمــين لأهم المشكلات التي تقف عائقاً أمام تدريسهم

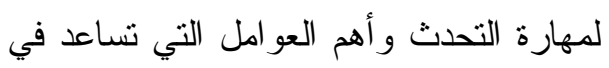


تطبيق أسلوب تدريس اللغة الاتـصالي فـي

المدارس التركية، وكذلك التعرف على أبرز

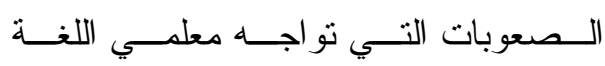

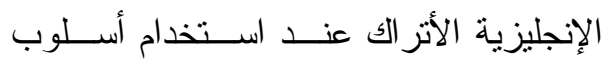

تدريس اللغة الاتصالي. و اســتخدم الباحــث

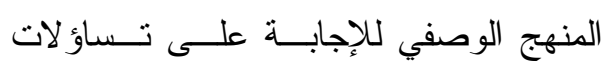
البحث من خلال الأدوات التالية: إبــنبانة و

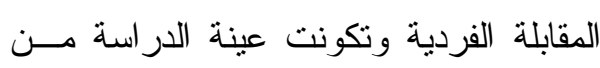
(79) معلم لغة انجليزية تركي.وكثنف نتائج الدراسة على أن أبرز الصعوبات المتأصــلـة التي تواجه تدريس اللغة الإنجليزية في تركيا

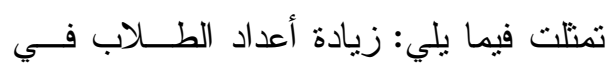
الفصول الدراسية، وكثرة الأعمال المـسندة إلى المعلمين، ونقص الدافعية لدى الطـــلاب،

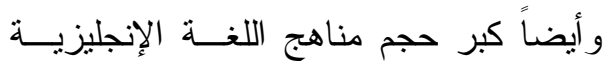
التركية. و على الرغم من أفراد العينة لـــيهر

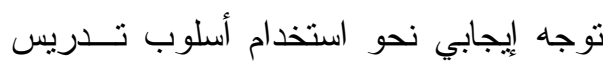

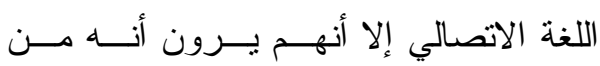
الصعوبة تطبيقه بفاعلية كبيرة فــي البيئــة الصنة التزكية وأكبر معيق لتحقيق ذلك هو نظــام

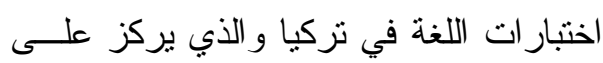
إتقان مهار ات القو اعد اللغوية.كذلك أظهرت نتائج الدراسة أن من أبرز الصعوبات التـي

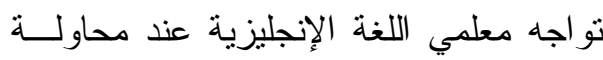
استخدام أسلوب تدريس اللغة الاتصالي تتمنل

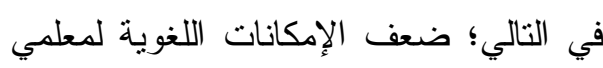

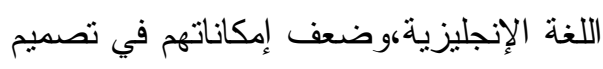

تدريس الاتصـال الــشفوي فــي المـــارس الثانوية الحكومية في مدينة كور اشيكي فـي لثي

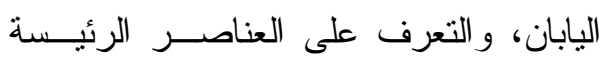

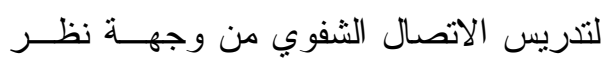

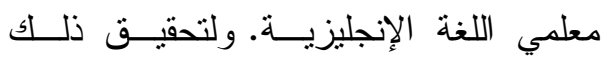
استخدم الباحث المنهج الوصفي للإجابة على الإنى تساؤلات الدراسة من خلال الأدوات التالية؛

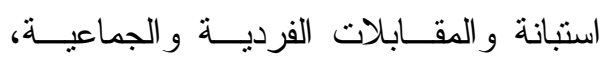

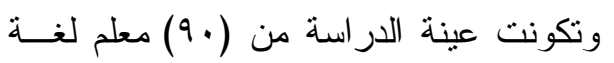

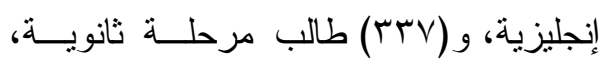

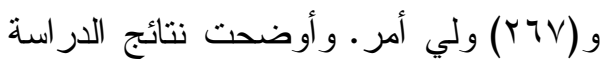

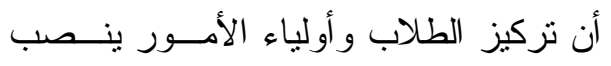

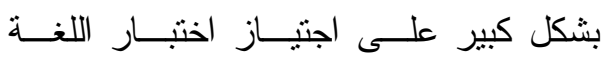

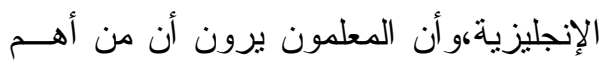
الأولويات هي مساعدة الطلاب على اجتيــاز

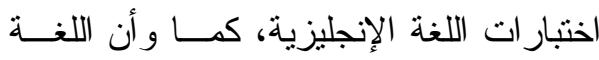
الإنجليزية تعد لغة غير محبوبة لدى الطلاب

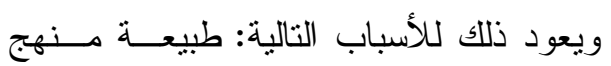

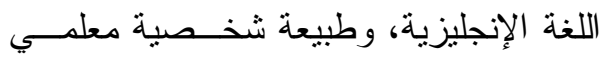

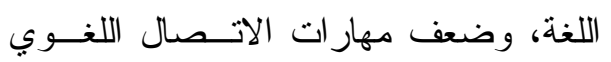
لديهم،و إحساس الطلاب بــأن مــادة اللغـــة

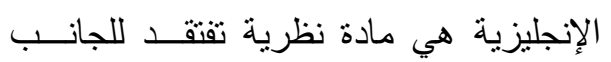
التطبيقي.

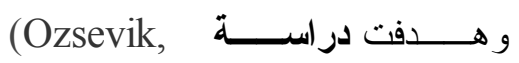

Zekariya, 2010)

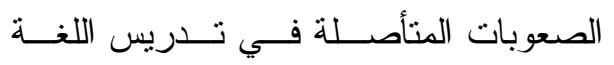
الإنجليزية في تركيا، و على مــدى إمكانيـــة 
و التز ابط (cohesion) و الطلاقة (fluency)

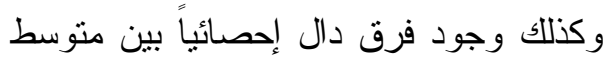
درجات المجمو عتين التجريبية و الضابطة في تطبيق اختبار التحدث البعدي لصـالح طــلاب

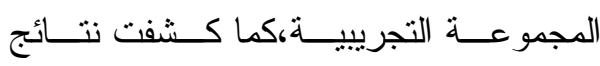
الدراسة عن آراء الطلاب الإيجابية تجاه تعلم مهار ات التحدث باللغة الإنجليزية باســتخدام تلأك الأنشطة.

التعليق على الارسات السابقة : من خلا استعر اض الدراسات السابقة تتبين الأمسـور النالية : - أثنتت معظم الدر اسات السابقة ضــــف مستوى الطلاب في التمكن من مهارات التحدث، وطلاب المرحلة الثانوية بصفة خاصة في عدم قدرتهم على التو اصــل

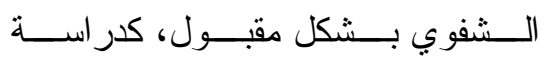
(Oradee,2012)، ودر اســـة (كمـــال

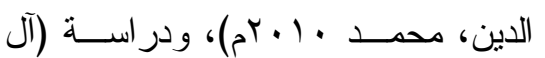

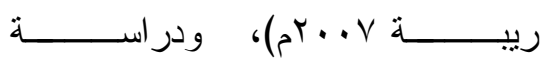
(Weide,1995) وبالتالي وجود حاجة ودران

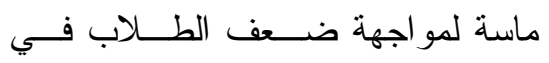

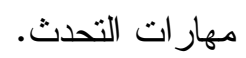

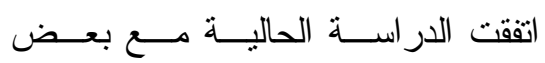

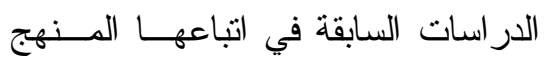

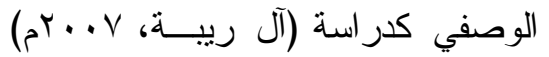

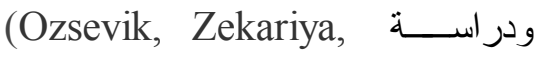
(Rapley, D. J. ودر اســـة 2010)
برامج وأنشطة تركز على استخدام أسـلـوب

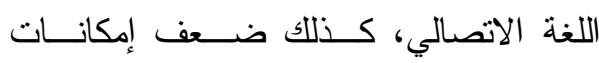

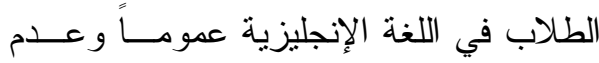
رغبتهم في المشاركة في الانشطة النتواصلية داخل الصف.

كما نادت دراسة (Oradee, 2012)

بتطوير مهار ات التحدث من خلال الأنـشطة دراته

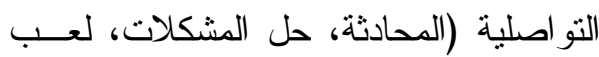
الأدو ار) ومقارنة أثز كل نشاط فـــي تتميــة

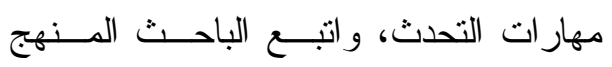
الوصفي بالإضافة للمنهج شــبه التجريبـي، لبهـ

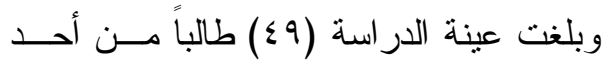
المدارس الثانوية في مدينة أودون (Udon)

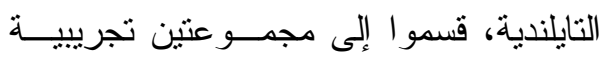

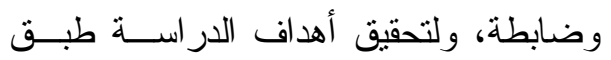
الباحث اختبار اً للتحدث نطبيقاً قبلياً وبعـدياً، و استخدم الاستبانة كأداة للكـشف عـن آر اء طلاب المرحلة الثانوية تجاه تعلم مهـارات

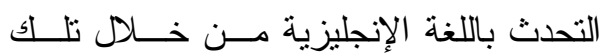
الأنشطة، و أظهرت نتائج الدر اسة عن فاعلية أنشطة التو اصل (المحادثة، حل المـشكلات، لعب الأدو ار) في تطور مهــار ات التحــدث

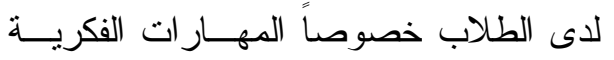

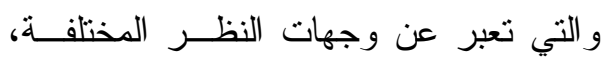

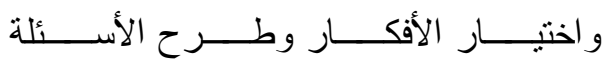
و الاستقسارات وتقبل آراء الآخرين، أيــضاً

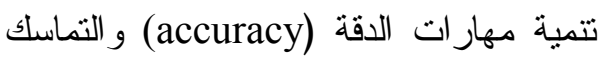


وبنــــاء بطاقــــة ملاحظـــــة كدر اســــة

(Farooqui, Sabrin 2006)

$$
\text { (آل ريبة V. . . م)م) }
$$

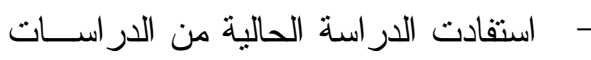

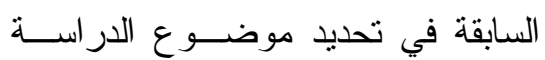

الحالية، وتحديد منهجيتها، وفي اختيــار

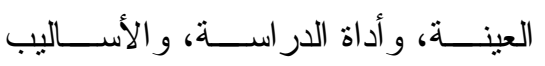

الإحصائية المستخدمة و التي كانت عوناً

في تصميم أداة الدر اسة وتطبيقها وفــي ولئي المعالجة الإحصائية للبيانات.

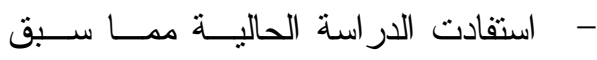

عرضه من دراسات في التعرف علــى

مهار ات التحدث، وكذللك في بناء أدوات

الار اسة، وتحديد المنهج المتبع فيها.

الإطار النظري:

مفهوم التحدث:

يعرف التحدث في القسم المخـصص

لمصطلحات البحث بأنه نرجمة المعلومــات

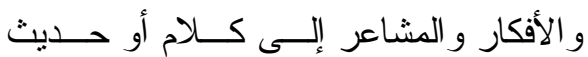

بالإنجليزية للتمكن من التفاعل مع الآخرين؛

وكما يتضح من هذا التعريف فهنالك عناصر

كثيرة مرتبطة بمهارة التحدث مما يجعل من من هن

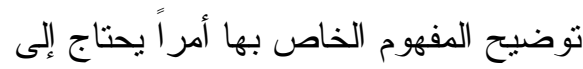

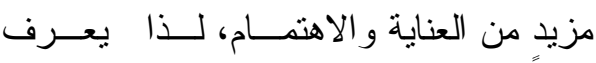

(Harris, 1996, pp81-82)

الإنجليزية بأنه "مهارة معقدة تتطلب استخدام

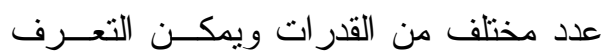

Farooqui, Sabrin ) 2008)

. (2006

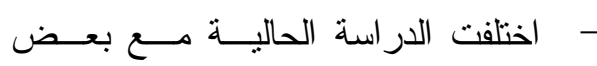

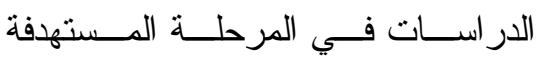

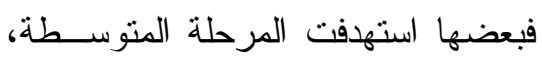

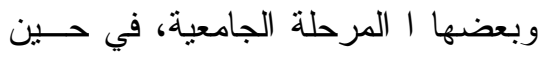

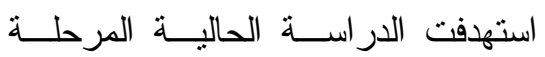

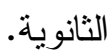

- - اختلفت الدراسة الحالية عن الدر اســات

السابقة مــن حيــث الحــدود المكانيــة

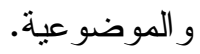

- - تلتوعت العينة المختارة فــي الدر ســــات

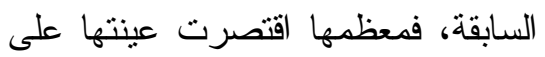

الطلاب و هذا مايتفق و الدر اسة الحاليــة،

وبعضها الآخر اسـتـهف المعلمــين -

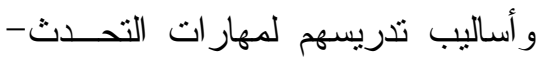

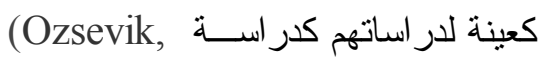

Rapley, ودر اسة Zekariya,2010)

Farooqui, ) ودر اسة ودراسة (D. J. 2008)

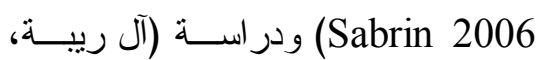

$$
\cdot(a+\cdot)
$$

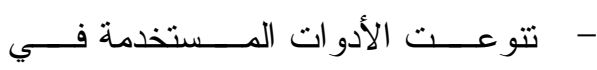

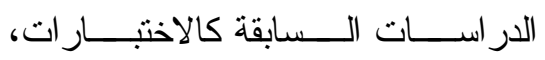

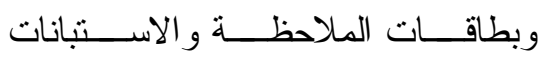

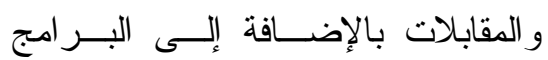

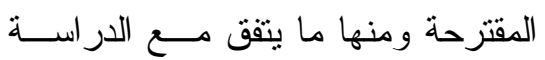

الحالية في إعداد قائمة بمهار ات التحدث 
المسموعة كلمات أو عبار ات أو جملاً. كما يمكن أن يكون التزكيز على النطق أو النبر أو التتغيم.

\&) اختبار المحاورة: وفيه يتم قياس قـدرة

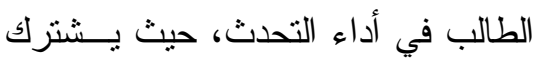
طالبين أو أكثر في حوار يتحدثون فيـــ

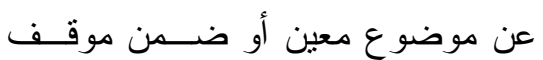
معين.

0) اختبار المقابلة الحرة: هنا يقابل المعلم الطالب على انفراد، ويوجه إليه أســئلة غير محددة مسبقاً أي ثتــو الى الأســــلة

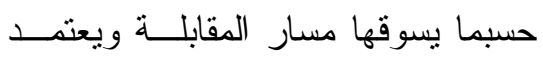
التقييم على طلاقة الطالــب و الــصحة اللغوية و النطقية كما يقول. على ســبيل

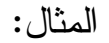

e.g. What is your name? What are your hobbies?

T) اختبار المقابلة الموجهة: هنـــا يكـون

المعلم قد أعد أسئلة محــددة مــن قبــلـل وتنير المقابلة وفقاً للأسئلة المعدة مسبقاً وفي هذه الحالة تكون الأســئلة موحـــة فيدة لجميع الطلاب. ( اختبار التعبير الحر:هنا يطلب المعلم من (V الطالب أن يتكلم لمــدة خمسس دقــائق (مثنلاً) عن موضوع ع يحدده له مثناً تكلم عن الحج، أو منزللك ومــن الجــائز أن يعطي الطالب فرصة لاختيار موضوع يفضله من بين عدة موضو عات.
على أربعة أو خمسة عناصر أثتـــاء تحليــلـ

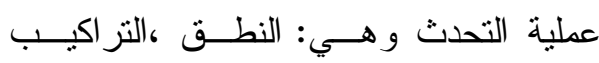
اللغوية ،المفردات،الطلاقة .

أساليب تقــويم مهــارة التــــدث باللغــة الإنجليزية :

ويلخص الباحثنان أهم أنواع اختبــارات

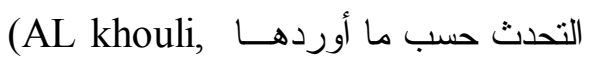

$$
\text { 2002) }
$$

( ) اتبار القراعة الجهرية: بعض المعلمين بطلب من كل طالــب أن يقــرأ فقــرة مختلفة عند اختبار القـــــاءة الجهريــة، و هذا غير عادل إذ يـستوجب أن يقــر أ

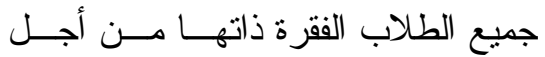

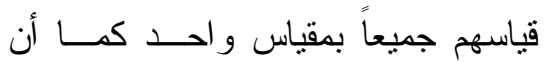
بعض المعلمين يستمع للقارئ ويـضـع

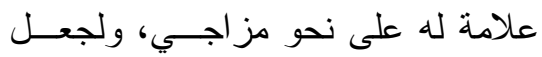
الاختبار موضوعياً فإن من الأفضل أن ولن يقوم المعلم باختبار كل فرد على انفراد ويركز على كميات معينة أو نقاط معينة تتعلق بجو انب مهارة التحدث.

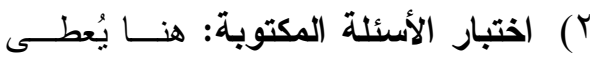

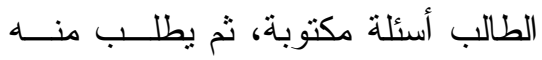
فردياً أن يجيب عنها شفهياً.

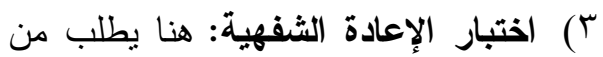

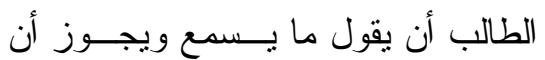

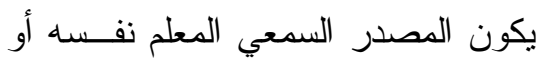

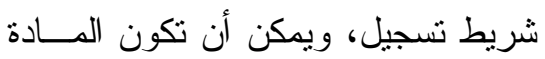




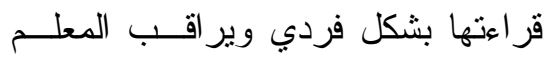
تتغيم الطالب لتلك الجمل.

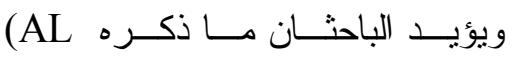

khouli,2002)

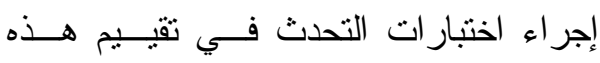

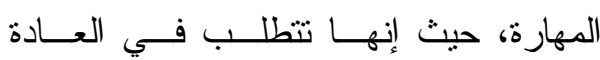

اختبار ات فردية مما بستغرق وفتاً طـــــالاً

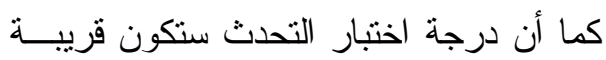

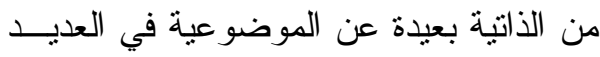

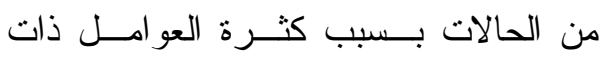

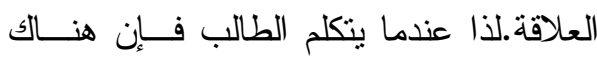

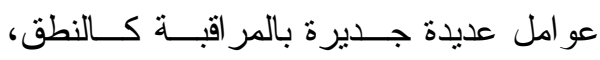

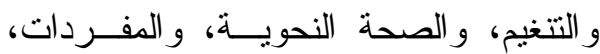

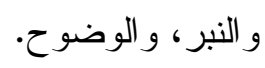

إجرائات الدراسة الميدانية:

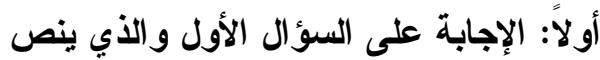

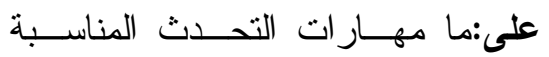

لطالبات الصف الأول الثانوي؟
ᄉ) اختبار الفونيمات: يحضر المعلم هنــــا

قائمة مكتوبة بكلمات منتقاة تحتوي كـلــل

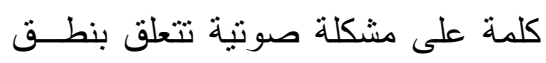

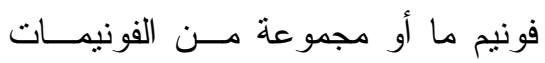

المنو الية، ويطلب من الطالب فردياً نطق

$$
\text { هذه الكلمات }
$$

e.g. Pronounce the following words: Park - bark - cheap - sheep - Leave - Leaf.

9) اختبار النبر: هنا يختار المعلم مجموعة

من الكلمات تظهر أمام الطالب في قائمة

مكتوبة. ويطلب من الطالب فرديــاً أن

ينطقها، وير اقب المعلم توزيع النبــرات

على المقاطع.

e.g. Prononnce these words: expensive - classmate international.

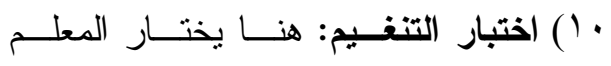

مجموعة من الجمل المتتوعة (استفهامية

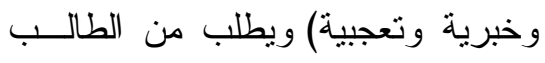

جدول (1)

\begin{tabular}{|c|c|c|c|}
\hline \multirow[b]{2}{*}{ درجة مناسبة المهارة } & \multicolumn{2}{|c|}{ المتوسط الحسابي } & \multirow{2}{*}{ م } \\
\hline & إلى & 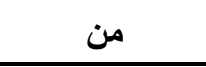 & \\
\hline مناسبة بدرجةٍ ضعيفة & $1,7 V$ & 1 & 1 \\
\hline مناسبة بدرجةٍ متوسطة & $r, r \varepsilon$ & أكثر من IV 1, 1 & r \\
\hline مناسبة بدرجة كبيرة & $r$ & أكثر من ع & $r$ \\
\hline
\end{tabular}

معيار الحكم على مدى مناسبة مهارات التحدث لطالبات الصف الأول الثاتوي

وجاءت النتائج المتعلقة بآر اء المحكمين على مدى مناسبة مهار ات التحدث لطالبات الصف

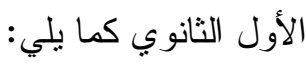




\section{جدول (ץ) (ץ)}

نتائج اتفاق المحكمين على درجة مناسبة مهارات المحور الأول من قائمة مهارات التحدث $(r \cdot=\dot{u})$

\begin{tabular}{|c|c|c|c|c|}
\hline درجة مناسبة المهارة & الالمحر اف & الحسابي & 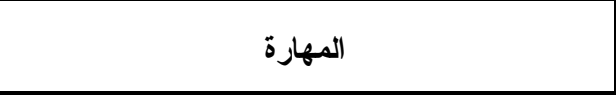 & s \\
\hline مناسبة بدرجة كبيرة & $\cdot, \Gamma$ & r,, . & منظد. تتحدث عن نفسها بأفكار مناسبة و بأسلوب مــوجز & 1 \\
\hline مناسبة بدرجة منوسطة & $\cdot$, or & $r, r V$ & تبأسلوب منتر الأفكار المناسبة للتعبير عــن موضــوع مـــا & r \\
\hline مناسبة بدرجة كبيرة & $\cdot, \leqslant 9$ & $r, 70$ & تطر ح أسئلة مرنبطة بالفكرة المر اد التحدث عنها. & r \\
\hline مناسبة بدرجة كبيرة &., 01 & r,o. & تستخدم الثنو اهد و الأفكار للتأكبد على صدق حديثها. & $\varepsilon$ \\
\hline مناسبة بدرجة منوسطة & $\cdot, 00$ & $r, 17$ & منظمة ترتب أفكار ها التي ترغب الحديث عنهـــا بطريقــة & 0 \\
\hline مناسبة بدرجة كبيرة & $\cdot, 0$ & $r, \Sigma\rceil$ & تجيب عن الأسئلة المطروحة بإجابات و افية & 1 \\
\hline مناسبة بدرجة كبيرة & $\cdot, r V$ & r,AO & تتحدث عن موضو ع ما بأفكار منسلسلة سهلة الفه. & $\mathrm{v}$ \\
\hline مناسبة بدرجة كبيرة & $\cdot, \leqslant \leqslant$ & r,Vo & تعبر عن آر ائها حول موقف ما بأفكار موجزة. & $\wedge$ \\
\hline مناسبة بدرجة كبيرة & $\cdot, \leqslant 9$ & $r, \Gamma \wedge$ & تحكى قصة قصيرة بأسلوب منز ابط منظم. & 9 \\
\hline مناسبة بدرجة منت سطة & $\cdot, 0 \wedge$ & $1,9 \varepsilon$ & تحسن الانتقال من فكرة إلى أخرى بسلاسة و انسيابية. & 1. \\
\hline مناسبة بدرجة كبيرة & $\cdot, \leqslant \uparrow$ & r,Tr & تصف شيئًا ما بأفكار مناسبة. & 11 \\
\hline مناسبة بدرجة كبيرة & $\cdot, 0$ & r, $\_$. & 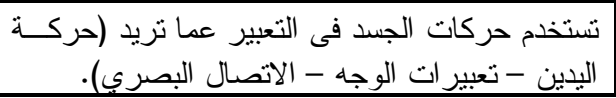 & it \\
\hline \multicolumn{2}{|c|}{ مناسبة بلرجة كبيزة } & r, $\leqslant 9$ & المحور الأول ككل & \\
\hline
\end{tabular}

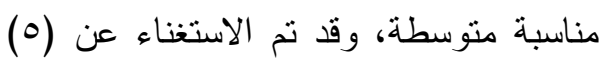

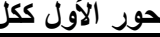

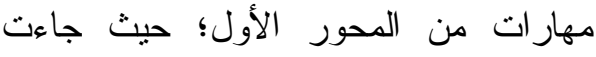
يتضح من الجدول (Y) أن المتوسط الاول

بدرجة مناسبة ضعيفة،وهي المهار ات رقم الحسابي العام لاتفاق المحكمين على درجة

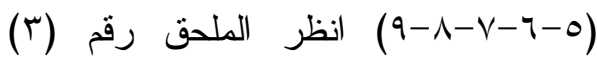
مناسبة مهارات المحور الأول من قائمة وبذللك اثثنمل المحور الأول من قائمة

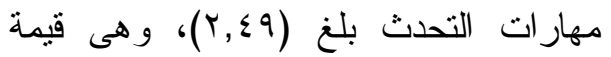
مهار ات التحدث على (r) (I) مهارة فرعية وذلك بعد إعادة نرتيب بعض المهارات وكذا إعادة صياغة البعض منها. تشير إلى أن مهار ات المحور الأول جاءت بدرجة مناسبة كبيرة، كما يتضح من الجدول

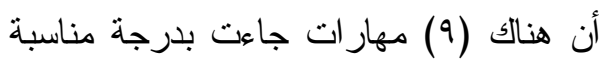
كبيرة، فى حين جاءت (ץ) مهار ات بدرجة 


\section{جدول (ץ) (ז)}

نتائج اتفاق المحكمين على درجة مناسبة مهارات المحور الثاني من قائمة مهارات التحدث $(r \cdot=\dot{0})$

\begin{tabular}{|c|c|c|c|c|}
\hline درجة مناسبة المهارة & الإسحر اف المياري & الحستوسط & 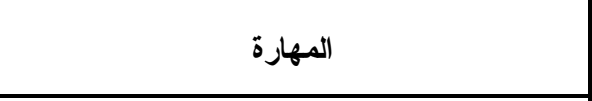 & s \\
\hline مناسبة بدرجة منوسطة & $\cdot, \mathrm{V} 4$ & $r, 1 \leq$ & المعنى. تستخدم منضـادات بسيطة لبعض الكلمات لتوضـــح & 1 \\
\hline مناسبة بدرجة كبيرة & $\cdot, 09$ & $r, 0 \leqslant$ & للمتوقف. بدقة المفردات و التز اكيب اللغوية المناســبة & r \\
\hline مناسبة بدرجة كبيرة & $\cdot, v_{1}$ & $r, \Sigma 0$ & 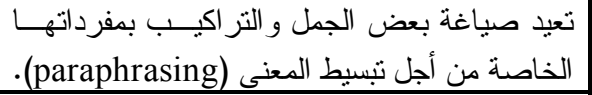 & r \\
\hline مناسبة بدرجة متوسطة & $\cdot \operatorname{tr}$ & $r, Y \leq$ & تستخدم: عبار ات الثكر و التحية والاعتذار استخداماً & $\varepsilon$ \\
\hline مناسبة بدرجة متوسطة & $\cdot, 77$ & $1, \wedge r$ & تملأ فر اغات التوقف عن الحديث بكلمات مناســبة & 0 \\
\hline مناسبة بدرجة كبيرة & $\cdot, \leqslant \varepsilon$ & $r, Y r$ & تتحدث عن موقف ما في تر اكيب لغويــة بـسيطة & 7 \\
\hline مناسبة بدرجة كبيرة & $\cdot, 0$ & $r, T \leqslant$ & تز اعي قو اعد اللغة أثناء حديثها. & v \\
\hline مناسبة بدرجة كبيرة & $\cdot, 7$. & r, $\varepsilon$. & تلستخدم أدو ات الربط (conjunctions) المناســبة & $\wedge$ \\
\hline مناسبة بدرجة كبيرة & $\cdot, v_{0}$ & 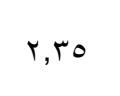 & 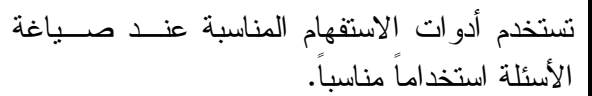 & 9 \\
\hline \multicolumn{2}{|c|}{ مناسبة بلرجة كبيرة } & r,ru & المحور الثاني ككل & \\
\hline
\end{tabular}

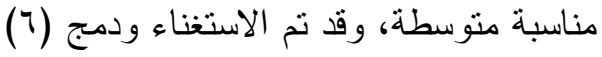
يتضح من الجدول (r) أن المتوسط مهارات من المحور الثاني؛ حيث جاءت الحسابي العام لاتفاق المحكمين على درجة بدرجة مناسبة ضعيفة وهي المهار ات رقم مناسبة مهارات المحور الثاني من قائمة ( ) (1) انظر الملحق رقم

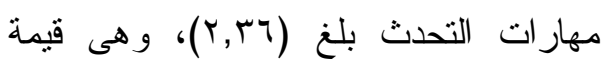
(r). وبالتالي اشتمل المحور الثاني من قائمة

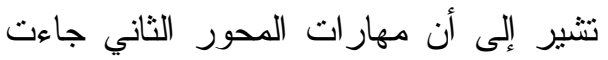
مهارات التحدث على (9) مهار ات فرعية بلدرجة مناسبة كبيرة، كما يتضح من الجدول

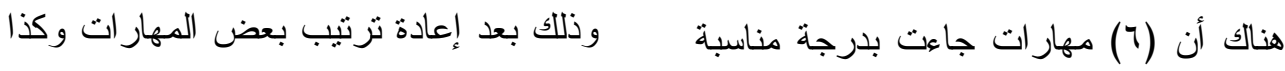
كبيرة، فى حين جاءت (r) مهارات بدرجة إعادة صياغة البعض منها. 


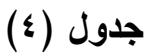

نتائج اتفاق المحكمين على درجة مناسبة مهارات المحور الثالث من قائمة مهار ات التحدث

$(r \cdot=\dot{0})$

\begin{tabular}{|c|c|c|c|c|}
\hline ل المهارة مناسبة & 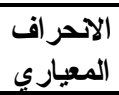 & المتوسط & 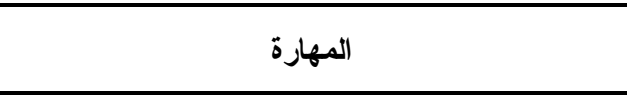 & b \\
\hline مناسبة بدرجة & $\cdot, 00$ & r, & نطق الكلمات و التر اكيب و الجمل نطقاً صحيحاً و اضحاً. & 1 \\
\hline مناسبة بدرجة كييرة & $\cdot, 0$ & $r, \varepsilon V$ & تتحدث بصوت و اثق متدفق و اضح. & $r$ \\
\hline مناسبة بدرجة كبيرة & $\cdot, \sum V$ & $r, V \cdot$ & $\begin{array}{r}\text { تميز نطقاً بين الأصو ات القريبة فى المخرجات منل: (A.B, (A,I) (C,S) } \\
\text { (P.B) }\end{array}$ & r \\
\hline مناسبة بدرجة & $\cdot, 7)$ & $r, 17$ & تتجنب الوقفات التي تؤدي إلى الإخلال بمعنى الفكرة. & $\varepsilon$ \\
\hline مناسبة بدرجة كبيرة & $\cdot, 0$ & $r, \uparrow \wedge$ & تتطق الكلماتٍ التئٍ تحتوي على الحروف الساكنة غير & 0 \\
\hline مناسبة بدرجة كبيرة & $\cdot, 01$ & $r, 00$ & 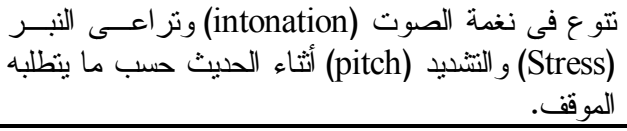 & 7 \\
\hline 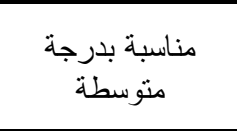 & $\cdot, \leqslant 9$ & 1,91 & 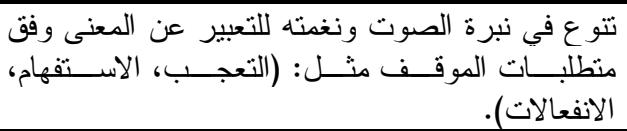 & $\checkmark$ \\
\hline مناسبة بدرجة كبيرة & $\cdot, \leqslant \varepsilon$ & $r, \vee \wedge$ & تسترسل في الحديث بدون وقفات تؤدي إلى عدم اكتمال & $\wedge$ \\
\hline من منبة بدرجة & $\cdot, 7 \varepsilon$ & $1, \wedge 7$ & تستطيع التحدث بلا تعثر و اضح أو توقف مخل باكتمال & 9 \\
\hline مناسبة بدرجة كبيرة & $\cdot, 01$ & r,Tr & 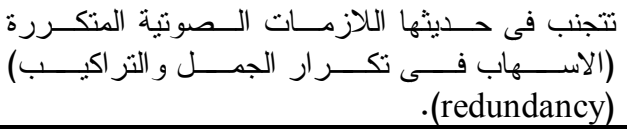 & 1 . \\
\hline \multicolumn{2}{|c|}{ مناسبة بلرجة كبيرة } & Y, \& & \multicolumn{2}{|l|}{ المحور الثالث ككل } \\
\hline
\end{tabular}

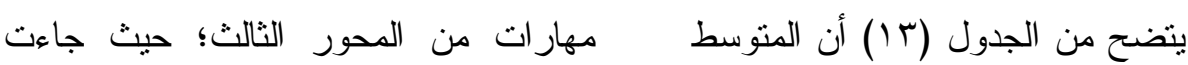

الحسابي العام لاتفاق المحكمين على درجة بدرجة مناسبة ضعيفة وكذلك دمج بعضها

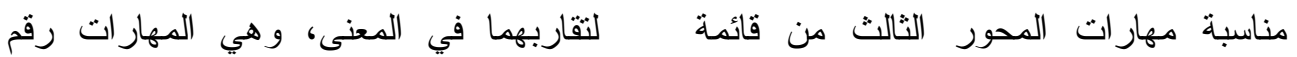

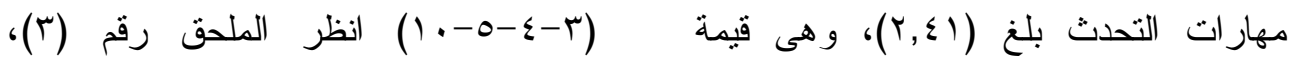

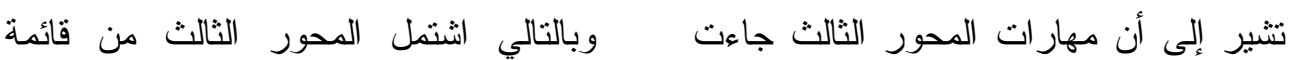

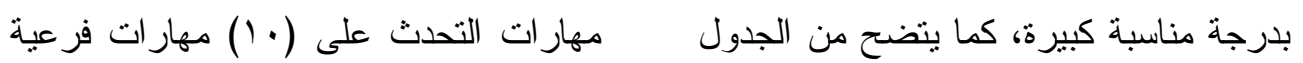

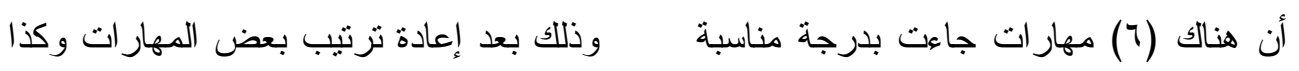

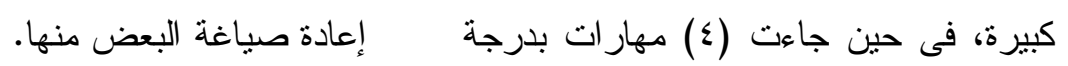

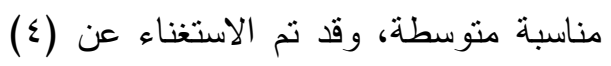


جدول (•)

المتوسط الحسابي الكلي لاتفاق الملاحظين على درجة مناسبة قائمة مهارات التحلث لطالبات الصف الأول الثانوي

\begin{tabular}{|c|c|c|c|}
\hline درجة مناسبة & الحسابي & محاور القائمة & م \\
\hline بدرجة كبيرة & $r, \Sigma q$ & اختيار الأفكار الجيدة وتنظيمها تنظيماً يناسب الموقف & 1 \\
\hline بدرجة كبيرة & ז ז, r & الخيتار العفردات والتز اكيب الصحيحة واستخدامها استخداماً يناسـب & r \\
\hline بدرجة كبيرة & $r, \xi)$ & الطلاقة ونطق الأصو ات و الكلمات و التر اكيب نطقاً صحيحاً & r \\
\hline بدرجة كبيرة & $r, \varepsilon r$ & اللدرجة الكلية للقائمة & \\
\hline
\end{tabular}

نص السؤال الفرعي الأول على: "ما

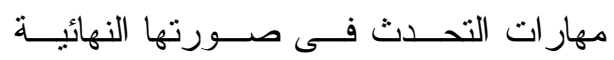

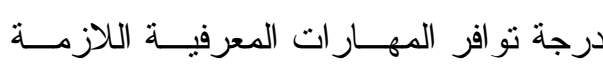

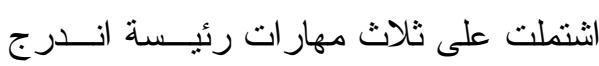

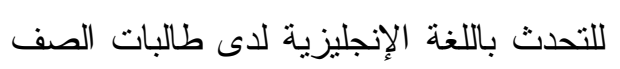

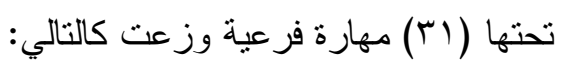

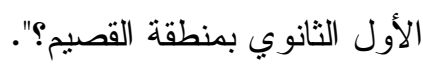

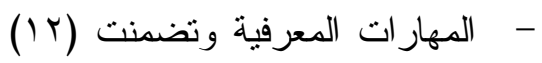

ولإجابة عن هذا السؤال، تم حسباب

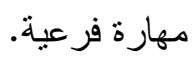

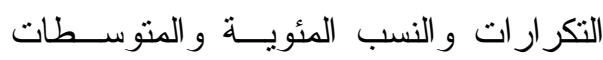

الحسابية والانحر افات الدعيارية لبيانات عينة

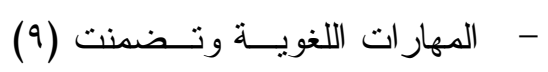

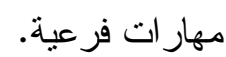

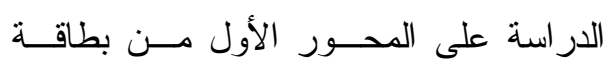

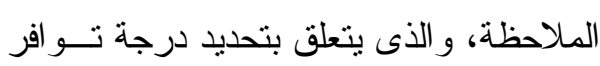

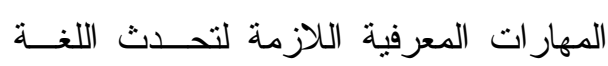

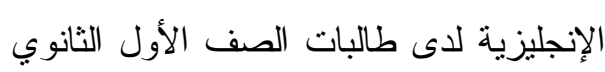

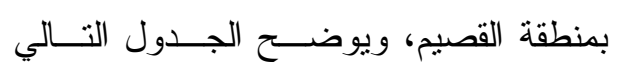

النتائج النى توصل إليها الباحثان:

- المهار ات الصوتية وتضمنت (· (1)

$$
\text { مهار ات فر عية. }
$$

ثانيًا: الإجابة على السؤال الثـاني والـــي

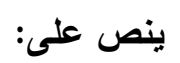
ما درجة توافر تلك المهارات لدى طالبـات الصف الأول الثانوي؟ تئ 


\section{جدول (7)}

نتائج بطاقة الملاحظة لتحديد درجة توافر المهارات المعرفية اللازمة للتحدث باللغة الإنجليزية

لاى طالبات الصف الأول الثاتوي بمنطقة القصيم (ن = I AV)

\begin{tabular}{|c|c|c|c|c|c|c|c|c|c|}
\hline \multirow[b]{2}{*}{ 雮: } & \multirow[b]{2}{*}{ 诵 } & \multirow[b]{2}{*}{ 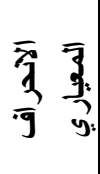 } & \multirow[b]{2}{*}{ 矛牙 } & \multicolumn{3}{|c|}{ درجة تو افر المهارة } & \multirow{2}{*}{ 司高哥. } & \multirow[b]{2}{*}{ المؤشرات } & \multirow{2}{*}{$\begin{array}{l}\sqrt{2} \\
\overline{3} \\
\text { 多 }\end{array}$} \\
\hline & & & & 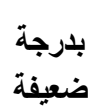 & متوسطة & كبيرة & & & \\
\hline \multirow[b]{2}{*}{1} & \multirow{2}{*}{ 年 } & \multirow[b]{2}{*}{$\cdot$, or } & \multirow[b]{2}{*}{1,10} & «1 & rז & $\pi$ & $ت$ & \multirow[b]{2}{*}{ تقدم نفسها بأفكار (ideas) } & \multirow[b]{2}{*}{1} \\
\hline & & & & r 1,9 & $v 1,1$ & $v, \cdot$ & $\%$ & & \\
\hline \multirow{2}{*}{ 。 } & \multirow{2}{*}{ : } & \multirow{2}{*}{$\cdot, 01$} & \multirow{2}{*}{1,00} & $9 \pi$ & ᄉT & $\Lambda$ & $ت$ & \multirow{2}{*}{ 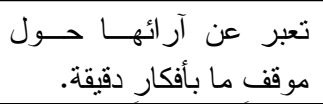 } & \multirow{2}{*}{$r$} \\
\hline & & & & $\varepsilon q, V$ & $\leqslant 7,$. & $\varepsilon, r$ & $\%$ & & \\
\hline \multirow{2}{*}{9} & \multirow{2}{*}{ 疋 } & \multirow{2}{*}{$\cdot, 01$} & \multirow{2}{*}{ I,rr } & ITr & 01 & $\varepsilon$ & $ت$ & \multirow{2}{*}{ تأتكدار منسلسلة موضلة عن الفهم. } & \multirow{2}{*}{$r$} \\
\hline & & & & $V \cdot, \tau$ & $r V, r$ & $r, 1$ & $\%$ & & \\
\hline \multirow{2}{*}{7} & \multirow{2}{*}{ : } & \multirow{2}{*}{$\cdot,\rceil \varepsilon$} & \multirow{2}{*}{$1,0 \mathrm{r}$} & 1.0 & TV & 10 & $ت$ & \multirow{2}{*}{ تستخدم الثوا اهد و الأمتلــــة } & \multirow{2}{*}{$\varepsilon$} \\
\hline & & & & $07, r$ & $r 0, \Lambda$ & $\Lambda$, & $\%$ & & \\
\hline \multirow[b]{2}{*}{$\varepsilon$} & & & & 70 & 117 & 7 & ت & تشتطيع وصــف الأثـــياء & \\
\hline & $\frac{1}{3}$ & $\cdot$, OT & $1,7 \wedge$ & $r \varepsilon, \Lambda$ & Tr,. & $r, r$ & $\%$ & بأفكـــــار (description) & 0 \\
\hline$x$ & f & سי & $1<0$ & 1.9 & $T \varepsilon$ & $1 \varepsilon$ & ت & تطـــرح ح أســـئلة مرتبطــــة & \\
\hline$v$ & :" & $\cdot, n$ & 1,27 & $0 \Lambda, r$ & $r \varepsilon, r$ & $v, 0$ & $\%$ & بالفكرة بطريقة منظمة. & 1 \\
\hline r & 里 & $<$ & $1 \mathrm{kq}$ & $\leq 7$ & 140 & 7 & $ت$ & تجيـــب عـــن الأســــئلة & $y$ \\
\hline 1 & & $\cdot, 2 N$ & $1, \sqrt{1}$ & $r \varepsilon, T$ & $V Y, Y$ & $r, r$ & $\%$ & المطروحة بأفكار مبانشرة. & \\
\hline & .9 & & & 111 & $T \varepsilon$ & 。 & ت & تكمل حكاية قصة قصيرة & \\
\hline$\wedge$ & 承 & $\cdot, 0 \leqslant$ & $1, \varepsilon$. & Tr,1 & $r \leqslant, r$ & $r, r$ & $\%$ & $\begin{array}{r}\text { متر ابطة. } \\
\text { (short story) }\end{array}$ & $\Lambda$ \\
\hline & & & & VY & 19 & ru & ت & نستخدم الإثـار ات & \\
\hline$r$ & 告 & $\cdot, 71$ & 1, vo & $r \Lambda, 0$ & $\varepsilon \vee, \tau$ & $1 r, 9$ & $\%$ & 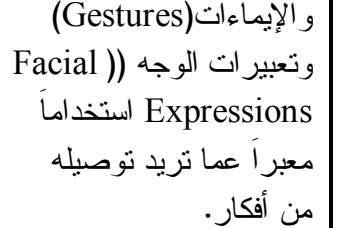 & 9 \\
\hline & جة ض & & 1,09 & & & 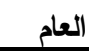 & ل طا الحسابر & المتوسد & \\
\hline (تقام & & حت & صل & ت ال & & كان أن & ات & 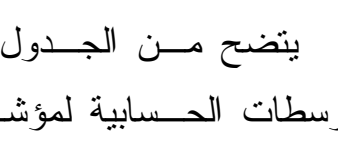 & \\
\hline
\end{tabular}


يليها العبارة رقم (^) ونصها (تكمل حكايــة

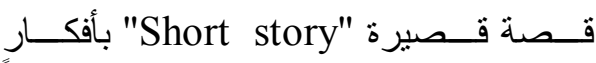
متر ابطة) بتقديرٍ ضعيف وبمتوسط حسـابي

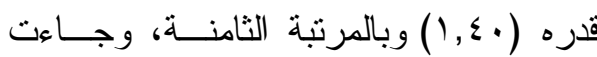

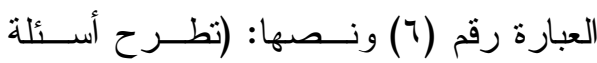
مرتبطة بالفكرة بطريقة منظمــة) بالمرتبـــة

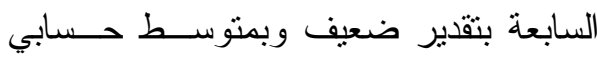

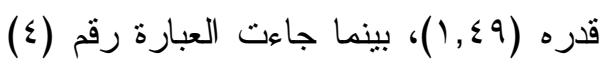

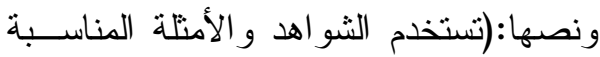
لتوضيح الفكرة) بالمرنبة الـسادسة بتقــديرٍ

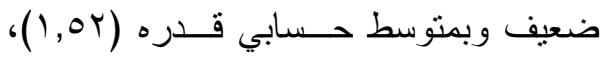
وكذللك العبارة رقم (Y) ونصها: (تعبر عـن ون

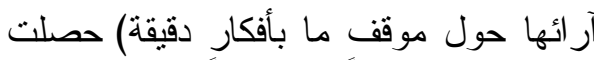

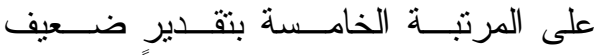
وبمتوسط حسابي قـدره (1,00)، ويعـزو الباحثان ذلك الضعف في تلك المهار ات إلـى عدة عو امل: منها ما يتعلق بالطالب، ومنهـــا ما يتعلق بالمعلم، ومنها ما يتعلــق بـــالمنهج

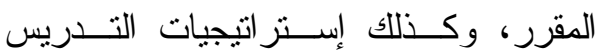

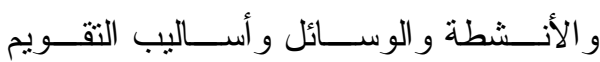

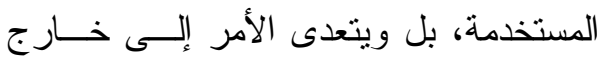

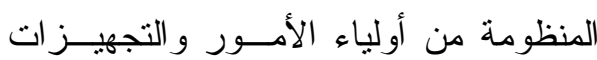
المدرسية. ويفسر الباحثان نتيجـــة ضـــف فئس مستوى الطالبات فــــي المهــــار ات المتعلقــــة بالتحدث عن موضوع ما بأفكارٍ منسلسلة و التي نالت المرتبة التاســعة فـي مسـستوى الضعف و التدني- إلى عدم معرفة الطالبــات
نفسها بأفكارٍ (ideas) و اضحة) على منوسط

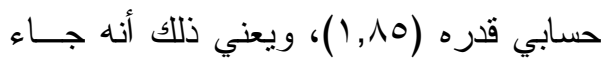

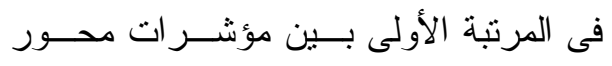

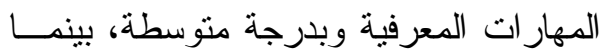
حصل المؤشر رقـم (ب): (تتحـدث عـنـ منـ

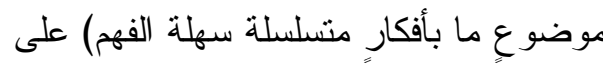

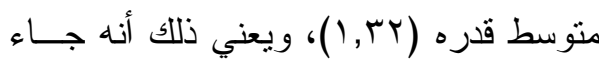

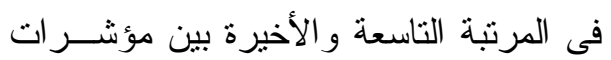

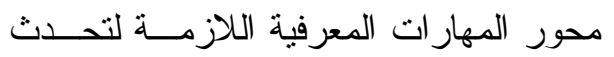
اللغة الإنجليزية لدى طالبات الــصف الأول الثانوي بمنطقة القصيم وبدرجةٍ ضعيفة. وقد بلغ المتوســـ الحـسابي العــام لمحور المهار ات المعرفية (1,09)، ويعنـي ذلك أن المهارات المعرفية اللازمة لتحــدث اللغة الإنجليزية تتو افر بدرجة ضعيفة لــى

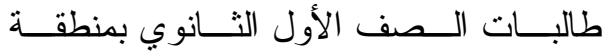
القصيم، وذلك في ضوء الملاحظات التي نم جمعها من عينة الدراسة. ويتضح من الجدول السابق أن خمس (0) عبار ات جاءت بمستوى ضعيف و أربع

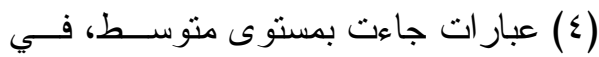
حين لم تأت أية عبارة بمستوى مرتفع. وفيما يلي تفصيل ذلك: جاءت العبــارة رقــم (ب) ونــصها: (نتحدث عن موضوعٍ ما بأفكـارٍ متسلــــلة سهلة الفهم) بتقديرٍ ضعيف وبمتوسط حسابي

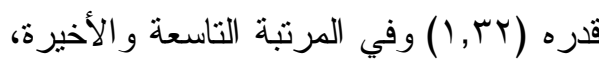


المهارة شيئًا ثانويًا لا ينبغي إلز ام الطالبــات

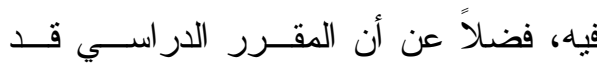

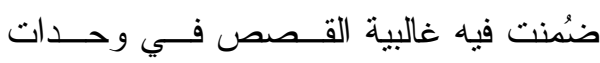
اختيارية (Optional) للإثز اء و التوسع فقط ويه وليس لزامًا تدريس تلك الوحدات، فوجــدت

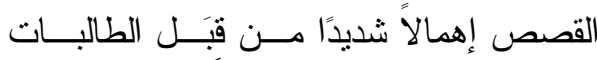

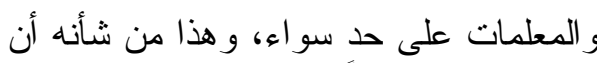

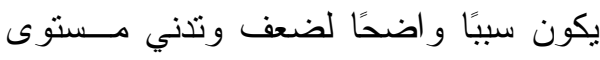

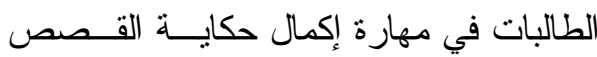

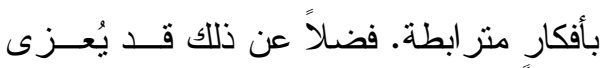

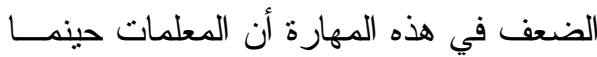
يُقدمن القصص للطالبات ويطلبن منهن إكمال وقائعها وتخمين نهايتها فإنهن يقدمنها بطريقة شفوية خالية من الصور التوضيحية الجاذبة، ونهية وخالية مــن عنــر التـشويق والإثـارة و الألوان، متجاهلات أن هناك فروق فرديـة

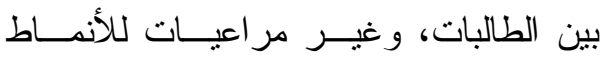
المختلفة للطالبات، فمنهن من يتمتــع بــنمط سمعي وبعضهن بنمط بصري أو لغــوي...

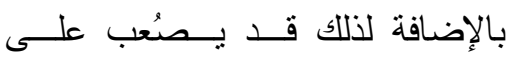

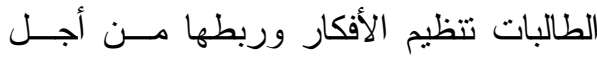

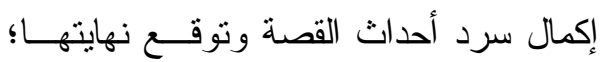
نظر اً لأن بعض القصص قد تكون من غيــر ثقافة الطالبات أو أقرب ما تكون شبه خيالية، وفي ذللك يرى كل من (Mixon \& Temu, وندان

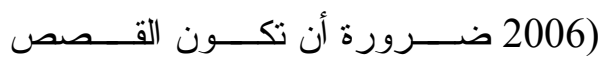

بطبيعة عملية التحدث وكيفية اختبار الأفكار وتتظيمها وترتيبها قبل وأثناء وبعد التحدث،

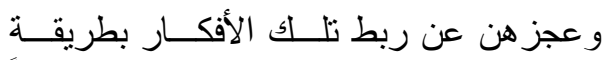

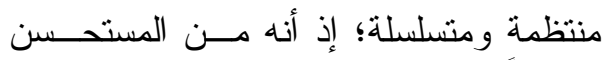
تدريس الطالبات طبيعة عملية التحدث وكيفية

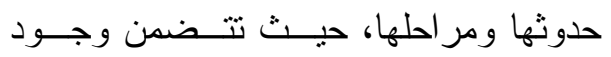

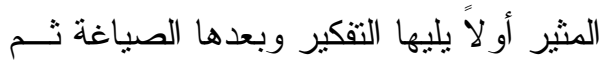

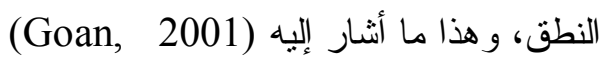
بضرورة تدريس الطــلاب كيفيــة عمليـــة التحدث و أنها عملية عقلية و أدائية فـــي ذات

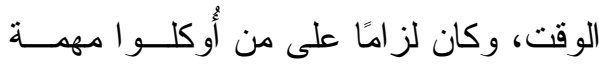

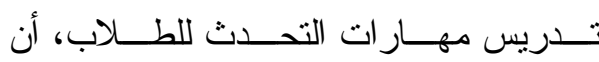

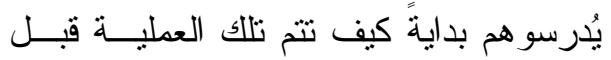
تدريسهم مهار اتها، وكيف للطلاب أن يفكرو البها في الموضوع المر اد التحدث عنه من حيــث

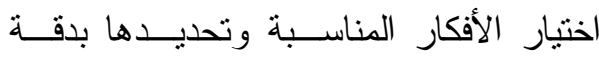
وترتيبها وتتظيمها، وبالتالي عرضها بطريقةٍ متسلسلة منطقية متر ابطة وو اضحة. وفيما يتعلق بالمهارة (تكمـلـ حكايـــة

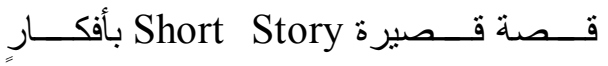
متر ابطة) فقد نالت المرتبـــة الثامنــة، وبــــــا

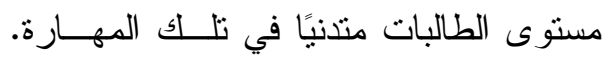

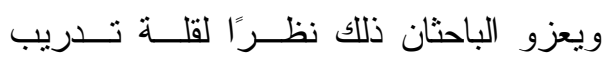
الطالبات على قص الحكايات وسرد القصص لفص دون من قبَل المعلمات، حيــث إن الكثيـــر مـــن

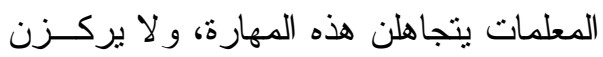

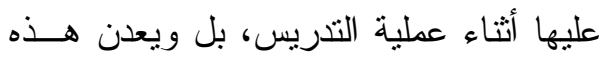


الطلاب في مهارة التحدث إلى وجود ضعف حاد في هذه المهارة تتمثل في عدم قـدرتهم على طر ح الأسئلة وتعليل ما يقولـــون، بــلـ امتد هذا الضعف ليشمل محصولهم اللغـــوي بوجه عام، مما بـستدعي إعـــداد البــر امج

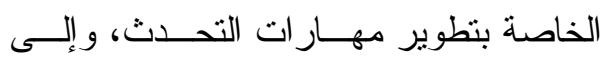
تذريب المعلمين بشكل كاف على تتفيذ هــذه

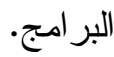
وربما تعود تللك النتائج إلى الاكتهـــاء فقط بقر اءة الفكرة أو الموقف الــذي يــدور حولـــه الموضـــوع بـــدون شــر ح "لفكـــرة الموضوع المر اد مناقشتهه" وتقديم التوضــيح الكافي الذي يساعد على الفهم، وربما يعـود ذللك إلى اعتقاد المعلمات بتحقق فهم الطالبات بالقر اءة فقط، ولكن بــدون إنــارة للخلفيــة المعرفية للطالبات لإثارة دافعيتهن للتحــــث لذا لابد كما ذكر (Smith, 1998) من تهيئة الطلاب للموضوع المر اد مناقـشتهـه وطــر حـ الأسئلة حوله بما يتناســب مسـع مسـستوياتهم اللغوية و الوقت المخصص لــذلك. ويمكـن تفعيل هذه المهارة من خلال المناقثة التـي ذكرت (Lazaraton, 2001) أنها الأكث: مهر استخدامًا لتتمية مهار ات التحدث في حجـرة

$$
\text { الدر اسة. }
$$

كذللك عدم تفعيل بعــض المعلمــات للأنشطة و الأسئلة الموجــودة فــي المقـرر الدر اسي بشكل كاف و التي تــساعد الطالبـــة
والحكايات من خلال ثقافة المتعلمين ونز اثهم الشعبي. ويجدها كثير" من البــاحثين تقنيــة فعالة لتعلم عنصر لغوي جديــــ كالتحـــثـ و القر اءة، وقد تشتعمل القصص و الحكايــات الثعبية المنتشرة في ثقافة المتعلم كبديل عن قلة الوسائل التعليميــة، حيـــث إن عنـــر

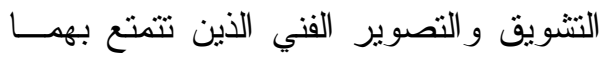
يثير ان خيال المتعلم وفـضـوله وتــصور اته، ويثحذن أفكاره حول نتائج الأحداث ونهايتها المتوقعة. و المعرفة السابقة للقصة باللغة الأم من شأنها أن تيسر (Mother Language) فهمها باللغة الإنجليزيـــة وترفــع تقــدير هم للذات. ويفترض (Oller) "أنه سيكون مــن السهل ربط الأفكار من أجل إكمال قـصة أو سرد بعض أحداثها أو توقع نهايتها إذا كانت مدعمةً بالصور وبعض الكلمات المـسـاعدة وذات بنيةٍ منطقيةٍ وجملٍ منر ابطة"، فيـسهل على المتعلم تتبع القــصة خطـــوة بخطـــوة ويسنطيع تذكر ها بيسر لبنيتهـــاـ المنطقيــة، (Csabay, وبذلك يقل الاعتماد على الذاكرة $.2006)$

أما مهارة (طرح الأسئلة المرثبطة

بالفكرة بطريقة منظمة ) فقد جاءت بالمرتبــة السابعة وبتقدير ضعيف. وتتفق هذه النتيجـــة ونتــائج در اســـة (Hughes, 1994) التــي حاولت الكثف عن الصعوبات التي يو اجهها 


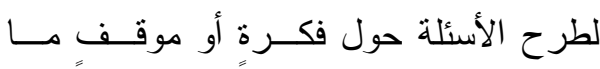

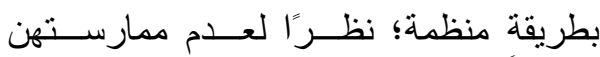
وتلقيهن التدريب الكافي من قبـــل معلمـــاتهن سو اءً في عمل ثثائي أو جماعي. بينما نالــت المهــار ات (تـستخدم الشو اهد و الأمثلة المناسبة لتوضيح الفكــــة و (تعبر عن آرائها حول موقفٍ مــا بأفكــارٍ

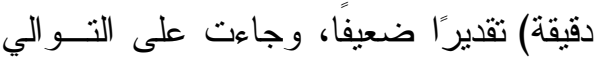

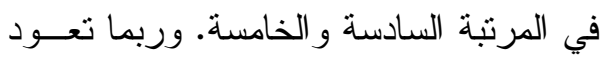
النتائج إلى عدم توفير وخلق وتهيئة المعلمات لمواقف تثير التحدث و التـي تـستلزم مسن لــن الطالبات استخدام الثنو اهد و الأمتلة لتـــعيم الفكرة، وكذلك للتعبير عن آرائهن ووجهات نظر هن تجاه موقفٍ أو موضوعرِ ما. كذللك اقتصار بعض المعلمات على الطرق الثقليدية في الثرح و عدم استخدامهن

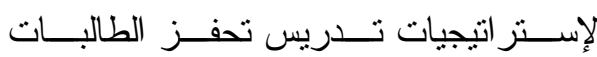
للتحدث، كلعــب الأدوار (Role Playing)،

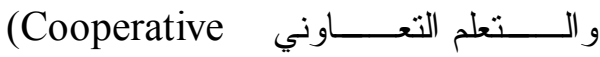

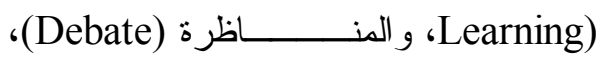
و المناقشة (Discussion)، وحل المشكلات (Problem Solving)

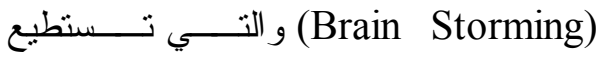
الطالبات من خلالها إبداء آر ائهن ووجهــات

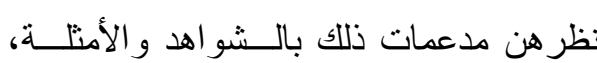

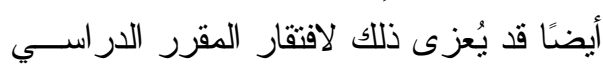

على التحدث وطرح الأسئلة وتفعيل اثشتر اكها مع زميلاتها في حجرة الدر اسة في المناقثة وطنة

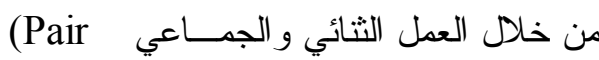
Work \& Group Work)

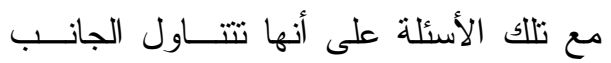

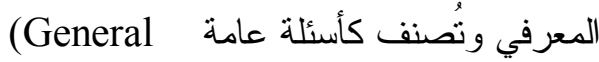
ونُوجه الطالبات بحلها كتابيً Questions) كواجب منزلي من أجل الاختبــار • وربمــا

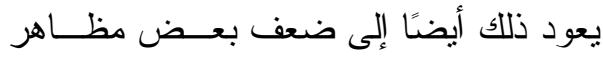

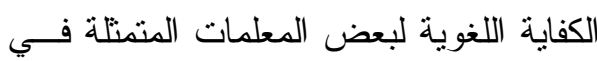

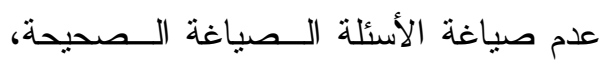
وتوجيه الطالبات وتلقي استفسار اتهن باللغـــة العربية، و عدم حتهن على اســتخدام اللغـــة الإنجليزية سواءً في طرح الأسئلة أو التحدث

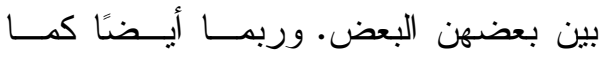

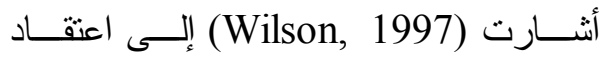
المعلمين أن توزيع الطلاب في مجموعـات

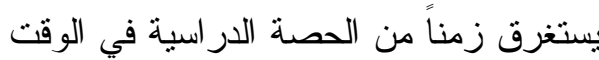

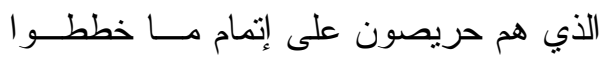

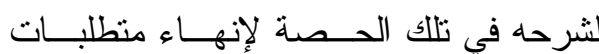
المقرر • وربما يعود السبب أيضًا كما ذكرت (Burkat, 1998)

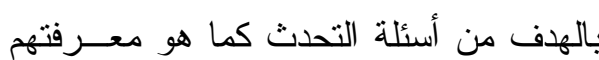

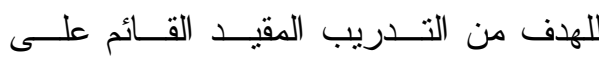

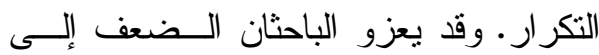
عو امل الخوف و الخجل و التزردد مــن قبَـــل الطالبات حيث لا يمتلكن الجرأة و الثقة التامة 


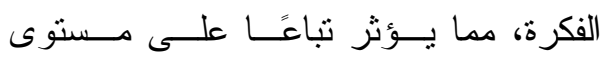
الطالبات.

وقد تعرف أيضًا بالرموز غير اللفظية

و التي تشمل أيضًا تحركات المعلمة و الطالبة

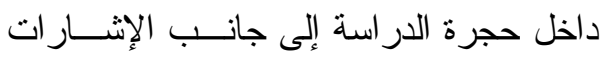

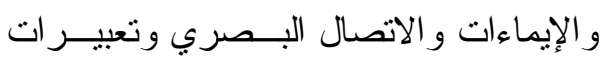

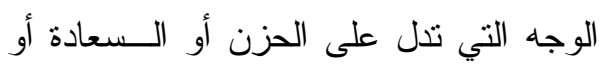
الفرح أو التعجب أو الاستقهام... الخ.

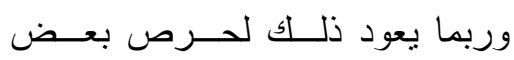

المعلمات على فهم الطالبات للرسالة اللفظية، فقد وظّف بعضهن بعـض الرمــوز غيــر

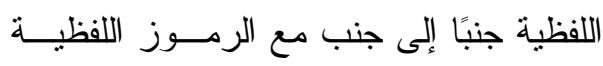
لإِيصال المحتوى المعرفي للطالبـات أثتـــاء تحدثهن و استماعهن إليهن. وربما يعود ذللك

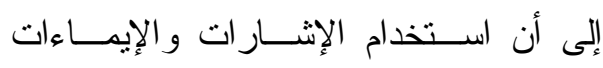
وتعبيرات الوجه وحركة اليدين من المهارات

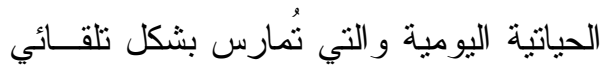

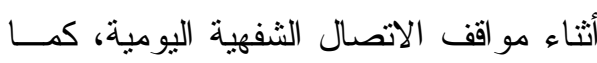
أن نكر ار مو اقف التدريس وخبرة المعلمة له له الأهاء

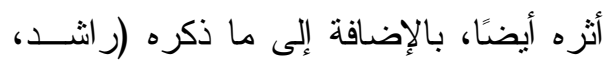

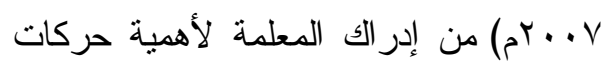
الجسد في إيصال الرسالة وتوضيح فكرنهـا إنسا

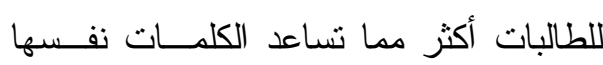
بالتأكيد على فكرةٍ معينة وشد انتباه الطالبات من خلال الاتصال البصري و النظري فـي ولئي

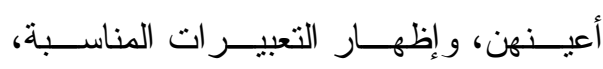
و استخدام الإيماءات منل حركة اليدين وهــز

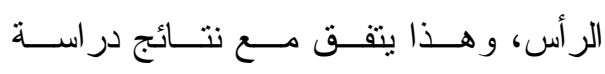

لمنل هذه الأنشطة و التمارين التي تزيد مــن دافعية الطالبات للتحدث. وجاءت المهارة رقم (0) ونــصها : (تستطيع وصــف الأثــياء Description بأفكارٍ مناسبة) بالمرتبــة الر ابعــة بتقــديرٍ متوسط ومتوسط حسابي قدره (1) 7 , )، بينما

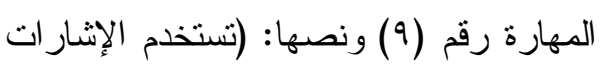

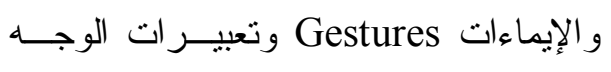
Facial Expression

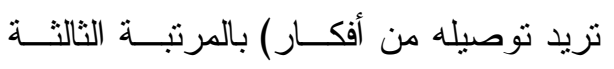
وبتقديرٍ متوسط ومنوســـ حسـسابي قــدره

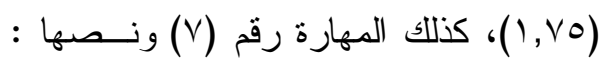
(تجيب عـن الأســئلة المطروحسـة بأفكـارٍ

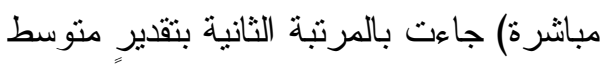
ومتوسط حسابي قدره (1, >9 ). في حين أن المهارة رقم (1) ونصها: (تقدم نفسها بأفكارٍ

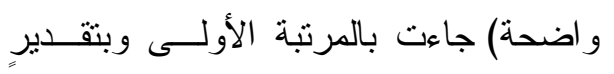
متوسط ومتوسط حسابي قدره (10, إنه ). وقد نالت تلاك المهارة مستوى متوسط لدى الطالبات ويعود سبب ذللك إلى تفــاوت

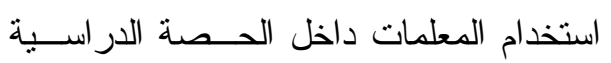

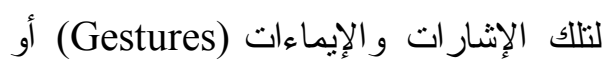
ما تُعرف بلغة الجسد (Body Language)

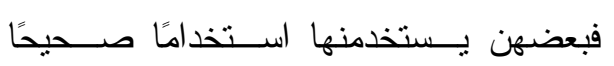

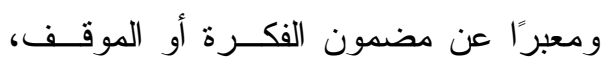
و البعض الآخر قد لا يكون مناسبًا لمضمون 


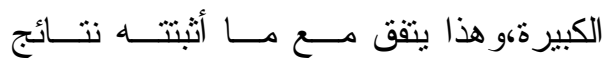

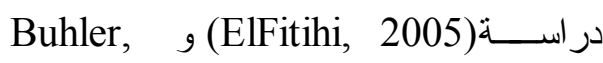
(2000) أن الاتصال البصري الحادث فـي

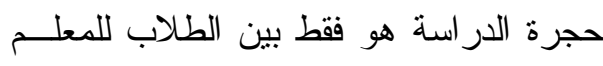

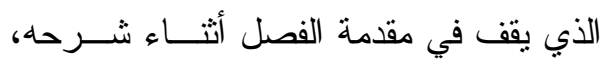
ولكن لا يتحقق ذلك عندما يوجه أحد الطلاب

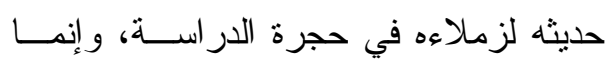

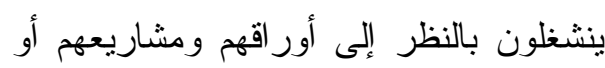

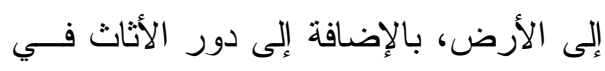

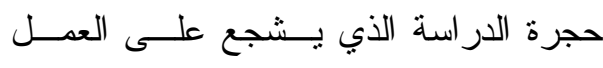

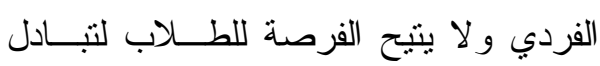
الحديث وتحقيق الاتصال واستخدام الإشارات

و الإيماءات المعبرة عن مضمون الحديث. وقد يعود السبب كذلك إلــى إغفــال المقرر الدراسي هذه المهارة و عدم التزكيــز

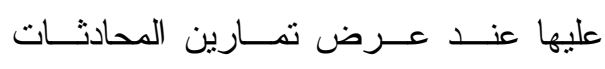
و المناقتشات، حيث يُطلب مــن الطالبـــة أداء

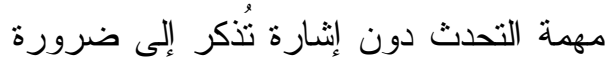

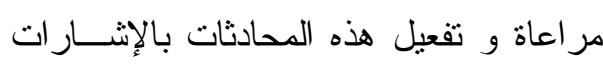

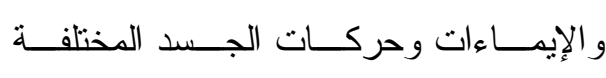
و المعبرة عن مضمون الفكرة و التي تعين في نقل الرسالة بصورةٍ أوضح و أسهل.

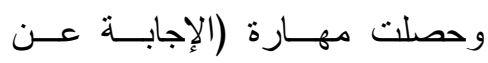

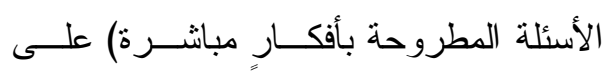

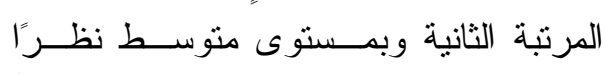

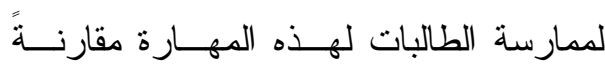

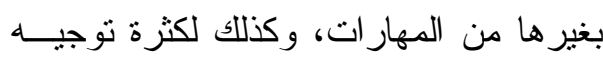

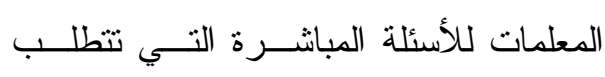

(ElFatihi, 2005)

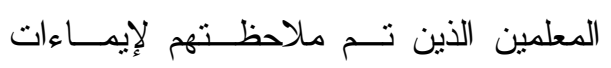

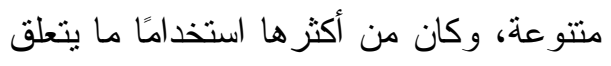

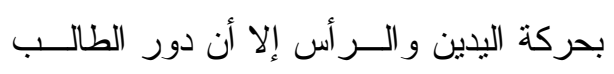
ينحصر في تلقي تلك الرموز غير اللفظيـــة

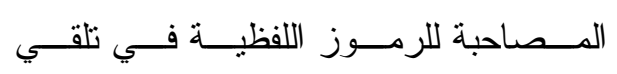
المعلومات فقط، وربما يعود لعــدم تفعيـلـل للرديل

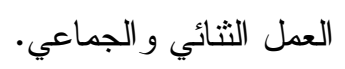
وقد يتوقف استخدام الطالبة للإثشارات و الإيماءات وحركة الجسد في رفعها ليــدها

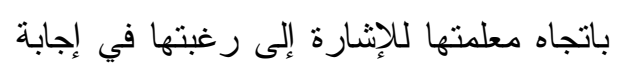

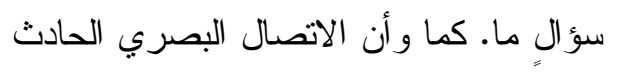
في حجرة الدر اسة هو من الطالبــات كــــل

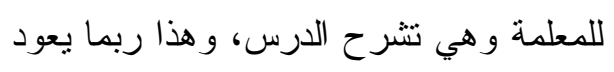

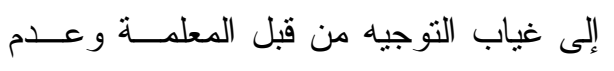
"تحركها بين الطالبات" وحثهن على استخدام

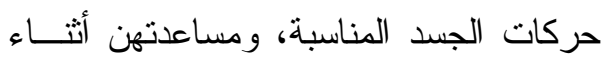
أداء المهام المطلوبة منهن، وتبادل الحـديث

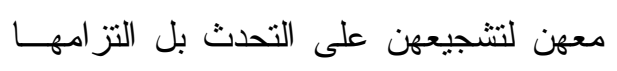

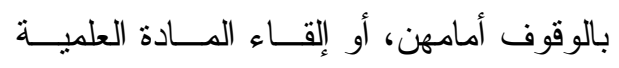

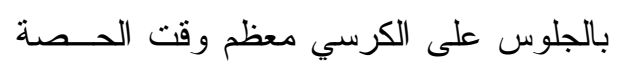

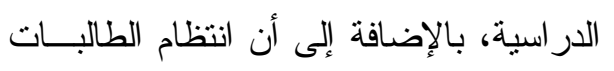
في صفوف و احدًا تلو الآخر لا يفسح مجــالاً النياً

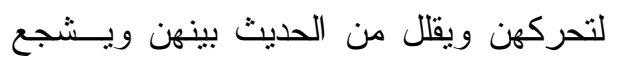

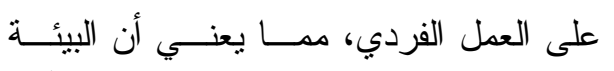

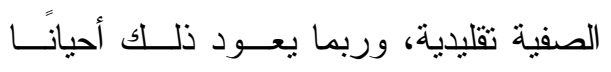

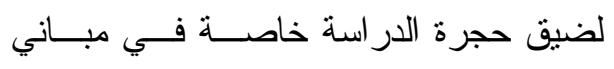

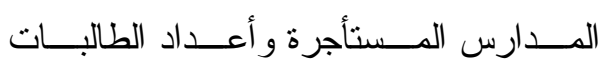




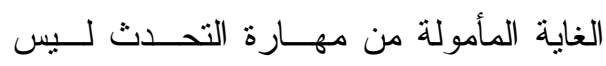
بالسهولة التي يظنها البعض، لأن إدرالك هذه

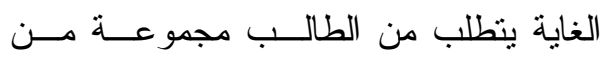

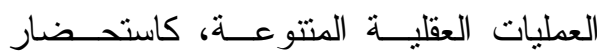

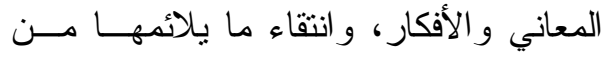
تز اكيب و ألفاظ، و القدرة على ربـــ الجمـلـل بعضها ببعض، وإتقان تسلسل هذه الأفكـار

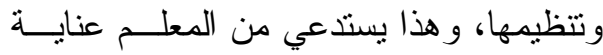

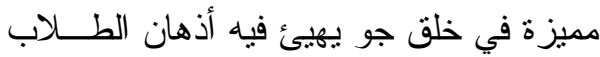
ليكثف عن جوانب القوة و الضعف لــديهه،

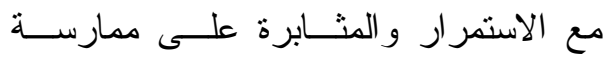

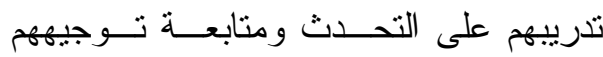
وتقويمهم في نهاية كل نشاط للتحدث. [ب] إجابة السؤال الفرعي الثاني: نص السؤال الفرعي الثــاني علــى:

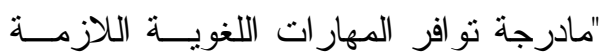

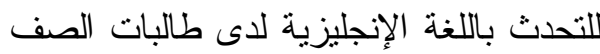

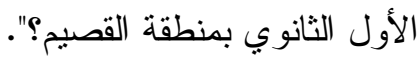
ولإجابة عن هذا السؤ ال، تم حسساب

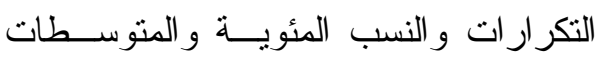
الحسابية و الانحر افات المعيارية لبيانات عينة الدراسة على المحور التــاني مــن بطاقـــة الملاحظة، و الذى يتعلق بتحديد درجة نو افر

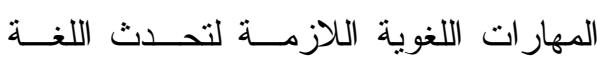
الإنجليزية لدى طالبات الصف الأول الثانوي

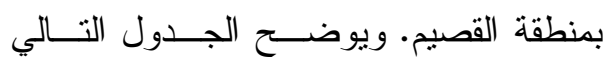
النتائج التى توصل إليها الباحثان:
الجو اب بأفكارِ مباشرة من الطالبات، وبالتالي

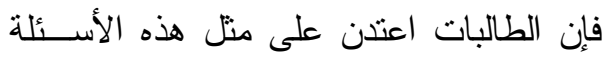
وطريقة إجابتها. و على الرغم من ذلك إلا أن بعض الطالبات لا يستطعن الإجابة بأفكـارٍ

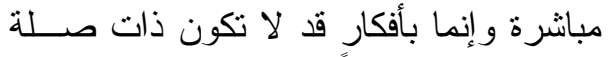
مباشرة بنوعية الأسئلة المطروحة، وتـشكل مهارة الإجابة عن الأسئلة المطروحة حيـزئًا و افرًا في المقرر الدراسي حيث تتو افر هــــه

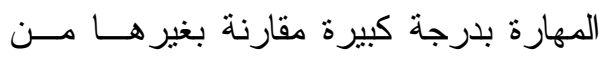

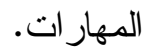
وحصلت المهارة التي نصها: (تقـدم نفسها بأفكار (Ideas) و اضحة) على المرتبة

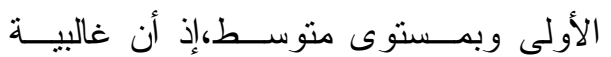

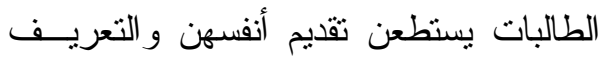
بهو اياتهن و اهتماماتهن بصورة جيدة. إجمالاً بهــذا يكــون المحــور الأول المتعلق بالمهارات المعرفية المتمنل "باختيار

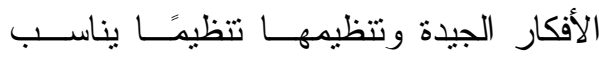

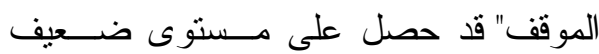
بمتوسط حسابي عام قــدره (1,09 1) و الــــي يعد مهارة أساسية من مهار ات التحدث التي ينبغي على الطالبات ممارستها بشكل مستمر منر وبالتالي إتقانها للوصول للمستوى المــأمول،

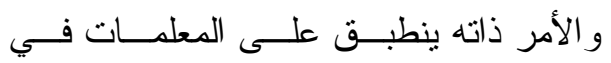
ضرورة تدريب الطالبات على تلك المهــارة وتتجيعهن المستمر على ممارستها بـشكل

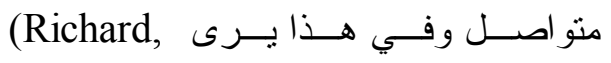
(Burns,2004) أن الوصول إلـى (2008) 


\section{جدول (v)}

نتائج بطاقة الملاحظة لتحديد درجة توافر المهارات اللغوية اللازمة للتحدث باللغة الإنجليزية

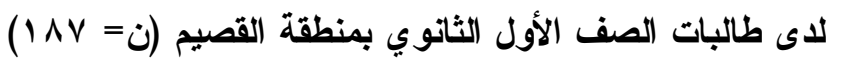

\begin{tabular}{|c|c|c|c|c|c|c|c|c|c|}
\hline \multirow{2}{*}{ 司: } & \multirow{2}{*}{ 氞 } & \multirow{2}{*}{ 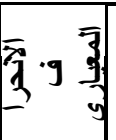 } & \multirow{2}{*}{ 牙 } & \multicolumn{3}{|c|}{ درجة توافر المهارة } & \multirow{2}{*}{ 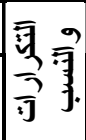 } & \multirow[b]{2}{*}{ المؤشر ات } & \multirow{2}{*}{ बृ. } \\
\hline & & & & ضلبعة & متوسطة & كبرجة & & & \\
\hline \multirow[b]{2}{*}{$\varepsilon$} & \multirow{2}{*}{$\frac{9}{3}: 0$} & \multirow[b]{2}{*}{$\cdot, \mathrm{OV}$} & \multirow[b]{2}{*}{$1, \wedge \varepsilon$} & $\varepsilon V$ & ITY & 11 & $ت$ & \multirow{2}{*}{ 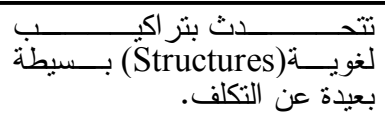 } & \multirow[b]{2}{*}{1} \\
\hline & & & & ro, 1 & $70, r$ & 9,7 & $\%$ & & \\
\hline \multirow[b]{2}{*}{0} & \multirow[b]{2}{*}{ 量 } & \multirow[b]{2}{*}{$\cdot, 07$} & \multirow[b]{2}{*}{$1, V 7$} & ov & $11 \mathrm{~V}$ & $1 \pi$ & $ت$ & \multirow[b]{2}{*}{ 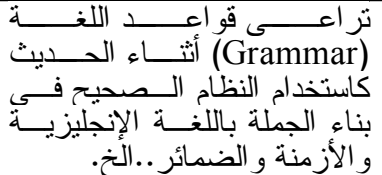 } & \multirow[b]{2}{*}{ r } \\
\hline & & & & $r \cdot, 0$ & $T r, 0$ & $\vee, \cdot$ & $\%$ & & \\
\hline \multirow[b]{2}{*}{ r } & \multirow{2}{*}{$\frac{3}{3}: 0$} & \multirow[b]{2}{*}{$\cdot, 7$} & \multirow[b]{2}{*}{1,90} & rर & $1 \%$ & rq & $ت$ & \multirow{2}{*}{ 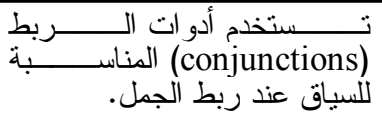 } & \multirow[b]{2}{*}{ r } \\
\hline & & & & $r \cdot, r$ & $T \varepsilon, Y$ & 10,0 & $\%$ & & \\
\hline \multirow[b]{2}{*}{ V } & \multirow[b]{2}{*}{ : } & \multirow[b]{2}{*}{$\cdot, 07$} & \multirow[b]{2}{*}{$1,0 \mathrm{~V}$} & $\Delta 7$ & 90 & 7 & ت & \multirow{2}{*}{ 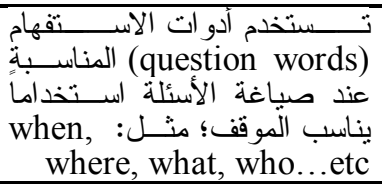 } & \multirow[b]{2}{*}{$\varepsilon$} \\
\hline & & & & $\leqslant \uparrow$, & $0 \cdot, 1$ & $r, r$ & $\%$ & & \\
\hline \multirow[b]{2}{*}{ r } & \multirow{2}{*}{ 量 } & & & 10 & $1 \leqslant 0$ & TV & $ت$ & & \\
\hline & & $\cdot, \leqslant \vee$ & $r, \cdot r$ & $\wedge, \cdot$ & $V V, T$ & $1 \leqslant, \varepsilon$ & $\%$ & تخنتار مفردات. & 0 \\
\hline & & & & 90 & $\wedge \wedge$ & $\varepsilon$ & $ت$ & تستخدم مر ادفات (synonym) & \\
\hline$\wedge$ & : & $\cdot, 0 \leqslant$ & 1,01 & $0 \cdot, \Lambda$ & $\varepsilon \vee, 1$ & $r, 1$ & $\%$ & 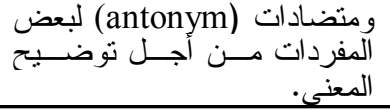 & 7 \\
\hline & & & & 110 & 79 & $\mu$ & $ت$ & 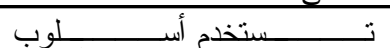 & \\
\hline 9 & 承 & $\cdot$, Or & $1, \varepsilon$. & 71,0 & r & 1,7 & $\%$ & تبسيط المعنى. (paraphrasing) & v \\
\hline & & & & $r$. & 119 & $\varepsilon \lambda$ & $ت$ & تـــــتخدم عبــــار ات الـــشكر & \\
\hline 1 & 㝵 & $\cdot, 09$ & $r, 10$ & $1 \cdot, \mathrm{V}$ & Tr, & $r_{0, V}$ & $\%$ & 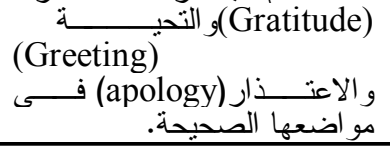 & $\wedge$ \\
\hline & & & & 71 & 119 & V & $ت$ & تملأ فر اغات التوقف عن الحديث & \\
\hline 7 & $\frac{1}{3}$ & .,or & $1, \times 1$ & $r, T$ & Tr, V & $r, \mathrm{~V}$ & $\%$ & 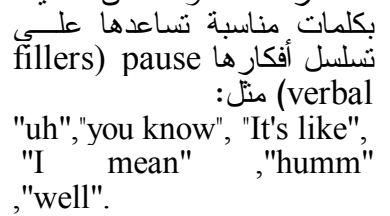 & 9 \\
\hline & متوس & بلدرجا & $1, V V$ & & & & & المتوسط الد & \\
\hline
\end{tabular}


ست عبار ات جاءت بمستوى متوســـ فـي حين لم تأت أية عبارة بمسنوى مرتفع، وفيما يلي تقصيل ذلك:

نالت المهـــارة رقـم (V) ونــصها:

(تستخدم أسلوب Paraphrazing من أجــل تبسيط المعنى)، و المهارة رقم (؟) ونــصها:

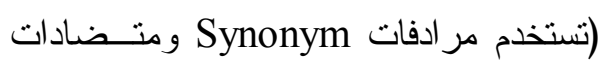

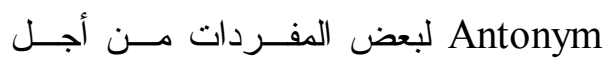

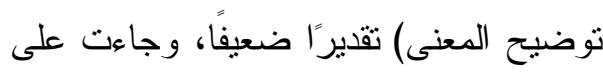
التو الي بالمرتبة التاسعة و الثامنة.

ويعزو الباحثان ذلك الضعف نتيجـــة

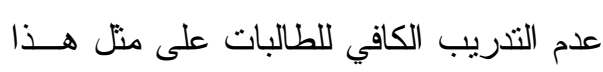
الأسلوب في تبسيط المعاني وتلخيص الأفكار

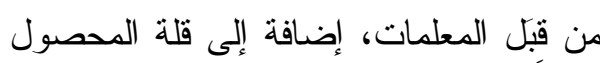

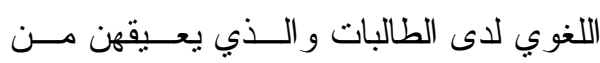

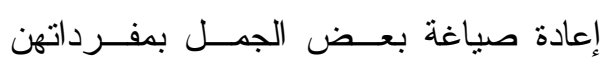

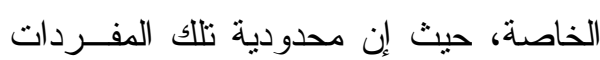

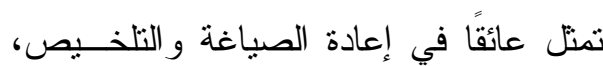
وفــي اســتخدام المر ادفــات (Synonym) وكذلك المتضادات (Antonym) من أجــل توضيح المعنى، لذا فإن استخدام الطالبــات

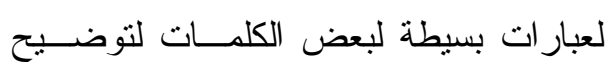
المعنى وتبسيطه نادرًا ما يحدث. لئل

وجاءت المهارة رقم (ع) ونـصها:

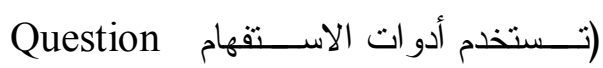
words

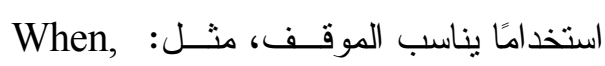

يتضح مسـن الجـدول رقــم (V) أن

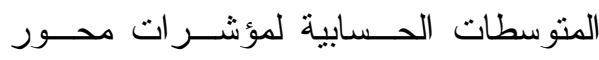

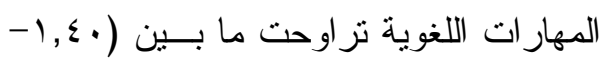
(Y,1)، وقد حــل المؤشــر رقــ (^):

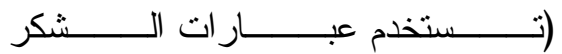

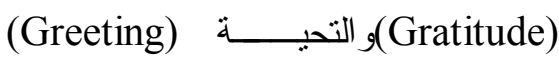

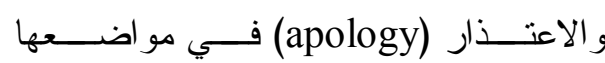

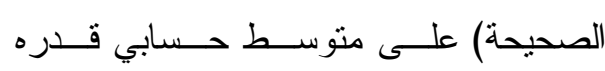

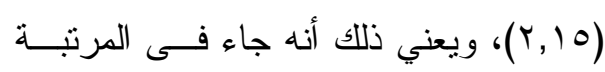
الأولى بين مؤشرات محور المهار ات اللغوية ولنية

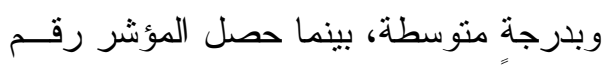

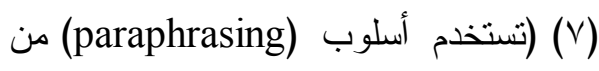

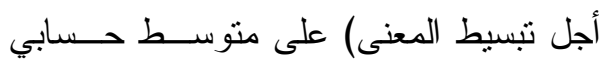

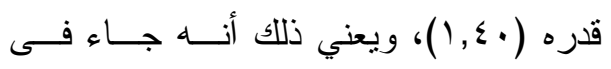

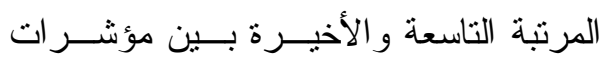

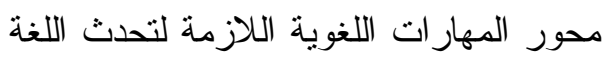
الإنجليزية لدى طالبات الصف الأول الثانوي بمنطقة القصيم وبدرجة ضعيفة. وقد بلغ المنوســــ الحسـسابي العـام

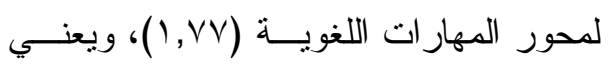

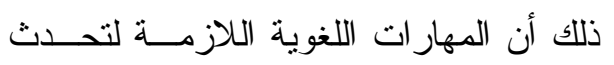
اللغة الإنجليزية تتو افر بدرجةٍ متوسطة لدى

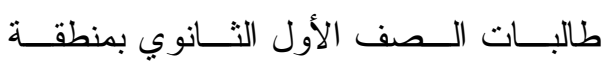
القصيم، وذلك فى ضوء الملاحظات الني تم

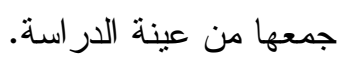
يتضح من الجـدول الــسابق أن (r)

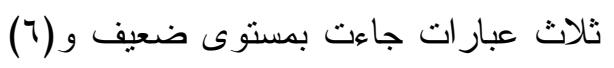


وتعود النتائج إلى اســتخدام بعــ

المعلمات لهذه المهارة أثناء شرحهن الدروس وفي أثتاء حديثهن اليــومي المباثــر مـــع الطالبات. و عند سؤال مجموعة من الطالبات عينة الدر اسة و الالتي تو افرت لــديهن هــذه المهارة بدرجة متوسطة إلى كبيرة أجبن بأن ذلك بسبب نزديد المعلمة علــى أســماعهن بعض العبار ات التي تقولها بين فترة و أخرى أثناء حديثها كتكر ار ها لكلمة "Well" وكذلك ."You know"

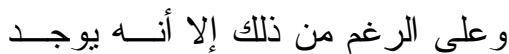

طالبات تو افرت لديهن هذه المهارة بدرجـة ضعيفة، ويعود ذللك لعدم اهتمـــامهن باللغـــة الإنجليزية خاصةً فيما يتعلق بمهارة التحدث وتتمية حــصيلة المفــردات اللغوبـــة التــي

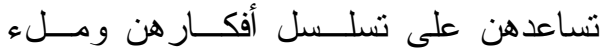

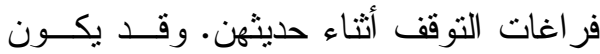
كذلك عدم كفاءة بعض المعلمــات القائمـــات

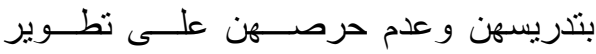
مهار اتهن اللغوية وندرة متابعتهن لما يستجد على الساحة التعليمبة فيما بختص بتطـــــر مهار ات اللغة الإنجليزية خاصةً فيما يختص بمهار ات التحدث، وتطوير أدائهن بالالتحاق

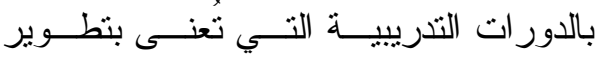
الاتــصال الــثفوي بمهارنيــــه الاســـتماع
Where, What, Who, ... etc) السابعة وبتقدير ضعيف.

كذلك قد يكون المقرر الدر اسي أحــــ أسباب ضعف الطالبات في هــذه المهـــارة؛ حيث لا يركز أحياناً على مهــارة اســتخدام

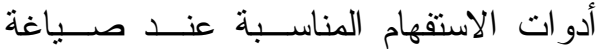

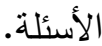

وقد يكون تفاوت مستويات الطالبــات

في هذه المهارة نظــرًا للتــصحيح المباثــر و الآني من قبل المعلمة The immediate) and direct correction) وقوعها في الخطأ أثناء استخدام أداة استفهام غير مناسبة للموقف أو الفكرة، ممـــا بــؤثز سلبًا على تقدمها في تلك المهارة ويؤدي بها

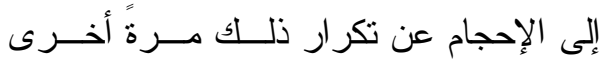

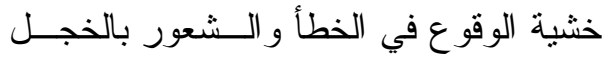
و الحرج ومن ثم بشعر ها ذلــــ بالإحبــاط، وتتضاءل رغبتها في الحديث، ونقل دافعيتها و واستعدادها للمبادرة.

وجاءت المهارة رقـم (9) ونــصها:

(تملأ فر اغات التوقف عن الحديث بكلمــات مناسبة تــساعدها علــى تسلـسـل أفكار هـــا "you مثــــ (Verbal pause fillers) know", "it's like", "Uh", "I mean", بالمرتبـــة الـــسادسة "humm", "well") وبتقديرٍ متوسط. 
أكثر من مهار ات الاستماع و التحدث، حيــث تحرص المعلمة علـى تــدريس الطالبــات المعلومات اللازمة لدر استها وحفظها، وتهتم بإثز اء حصليتهن اللغويــة مــن المفــردات

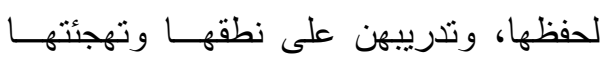
بالتكر ار ليس للمفردات فقط ولكن للعبــار ات

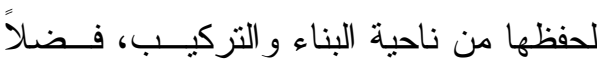
عن تركيز الأهداف الخاصة لتدريس اللغـــة

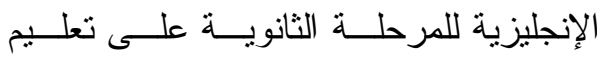
استخدام المفردات و العبار ات و الاصطلاحات و التعبير ات وفهم معانيهـــا داخــلـ الـــسياق. و أيضًا قد تعود النتائج لاســتخدام المعلمـــات لطريقة القو اعد و الترجمــة - Grammar ) Translation Method) الإنجليزية والتي تزكز على تدريس كثير من المفردات عن طريق وضعها في قو ائم طويلة ليسهل حفظها. وكذلك استخدامهن للطريقـة الإدر اكية المعرفيـة - The Cognitive وتعطي هذه الطريقة كما ذكرت (Al-Mutawa \& Kailani, كـل مـن (1994 المفردات و القو اعد النحوية اهتمانًا كبيرًا بوصفها من أهــم أسـاســيات اللغــة. وتشتخدم بعض الطالبات عبــار ات الــشكر و التحية والاعتذار طبقًا للموقــف اســتخدامًا سليمًا، بينما تستخدمهن أخريات في مواضع قد لا تكون مناسبة إلى حد ما؛ وقد يعود ذلك إلى قلة الفرص المتاحة وندرة المواقف التي
وحصلت المهارة رقم (Y) ونــصها:

(تر اعي قو اعـــد اللغـــة Grammar أثتــــاء الحديث كاستخدام النظام الصحيح فــي بنــاء

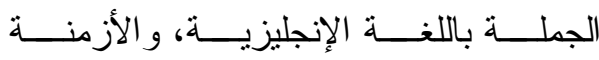
و الضمائر ... الـــخ)، و المهـــارة رقـــ (1) ونصها: (تتحدث بتر اكيب لغوية Structure بسيطة بعيدة عن التكلف)، و المهارة رقم (r)

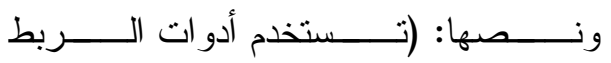
Conjunctions الجمل) على تقديرٍ متوسط وجـــاءت علــى التو الي بالمرنبة الخامسة و الر ابعة و الثالثة. وحصلت المهارة رقم (0) ونــصها: (تختـــار مفــردات Vocabulary مناســبة للسياق)، وكذلك المهارة رقم (^) ونــصها: (تستخدم عبار ات الشكر Gratitude و التحية

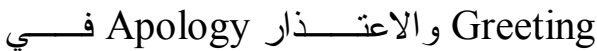
مو اضعها الصحيحة) على تقــدير متوســـ وجاءت علــى التـــوالي بالمرنبـــة الثانيـــة

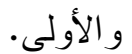

وتقاوتت درجة تو افر تلك المهــار ات

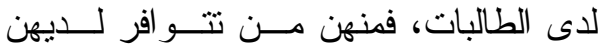
بدرجة كبيرة وبعضهن بدرجـة متوســـة

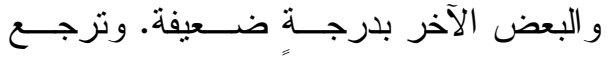
الأسباب إلى تركيز غالبية المعلمــات علــى تدريس المفردات وطرق اكتسابها. وكــذللك تزركيز المقـرر الدراســي علــى تــدريس المفردات و القو اعد ومهار ات القراءة و الكتابة 
والاستخدامات المختلفة لها، و لابد للمعلمــة أيضًا أن تزيد من دافعية الطالبات بتــصميم قاموس خاص لكل طالبة يتضمن كل مفــردة

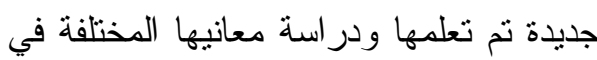

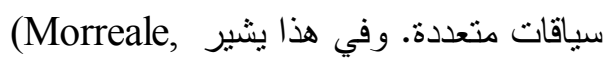
(2000 إلى ضرورة إثر اء الرصيد اللغــوي لنئي للطالب لبتمكن من استخدامه استخدامًا سليمًا.

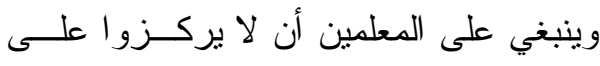

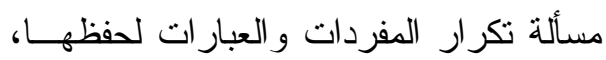

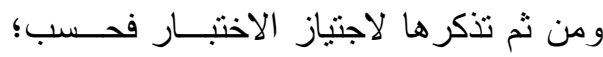

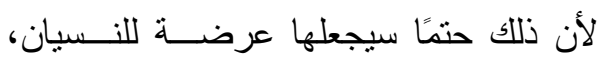

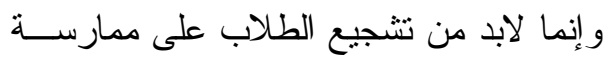

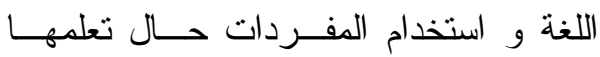
ووضعها في جمل تامـــة وتر اكيــب لغويـــة سليمة، من شأنها أن تثقي أثز تعلمها وبالتالي ونتي استخدامها في مو اقف مشابهة.

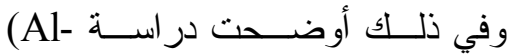
أن Dabbous, Jawaher, 2002) المتعمين الذين أتموا دراسة اللغة الإنجليزية

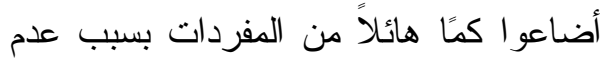
استعمالها (خمول المفردات) مقارنةً بهـــؤلاء الذين يستعملون المفردات حال تعلمها.كمـــا يستحسن تقديم المفردات للطالبات بـصورة غير تقليدية كأن يتم شرح معانيها من خلال

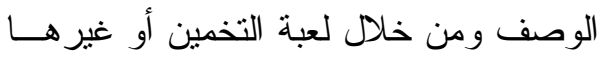

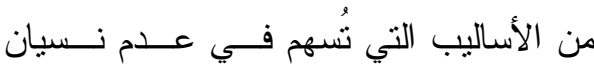

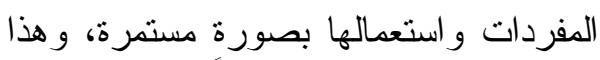

تحتم استخدام منل تلك العبار ات، وحتى وإن

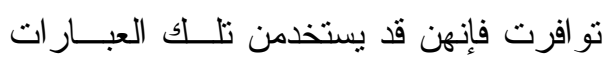

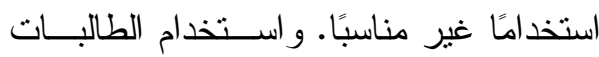
للمفردات و اختبار ها الأنسب حسب وانب الـسياق إنما يتم بإدر اكهن للمعاني المختلفة للمفــردة الو احدة خلال سياقات متعددة. إجمالاً جاء المحور الثــني المتعلــق بالمهار ات اللغوية و المتــضـمن الدقـــة فـــي القو اعد واختيار المفردات بتقديرٍ عام منوسط

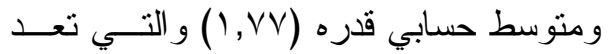

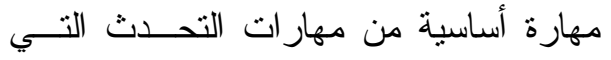
ينبغي على الطالبات التدريب عليها ومن ثــم مهن ممارستها للوصول لحد الــتمكن و الإتقــان، وكذا الأمر بالنسبة للمعلمات و اللاتي يحاولن

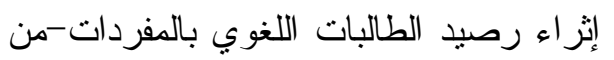
خلال شروح الدروس المضمنة في المقـرر

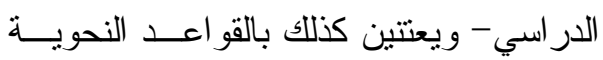

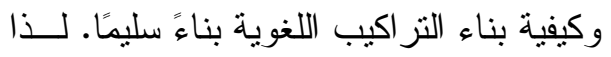
يرى الباحثان أنه من المستحسن أن لا تلتزم

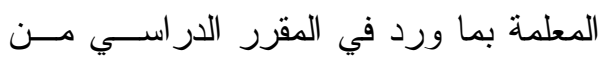

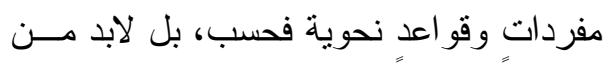
حث الطالبــات وتــشجيعهن علــى البحــث و الاكتشاف لمزيد من الإثراء و التوسع مـن

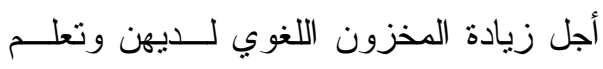
مفردات جديدة تضاف إلى قاموســــن، مـــع

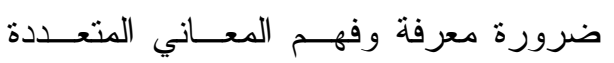
للمفردة الواحدة حسب ما نأتي فــي الـسياق 
(المفردات - القو اعد) - المهارات الصوتية

(النطق - الطلاقة)، و اشتملت نلك المهارات

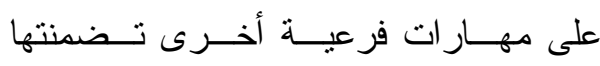
القائمة.

وبلغ المتوسط الحسابي الكلي لبطاقـــة

ملاحظة مهارات التحدث باللغة الإنجليزيـــة

(1, (1, (1)، مما يدل على أن المهار ات اللازمة

لتحدث اللغة الإنجليزية تتو افر بدرجة ضدان التعيفة

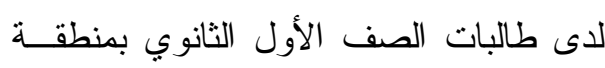

القصيم، وذللك فى ضوء الملاحظات التي نم

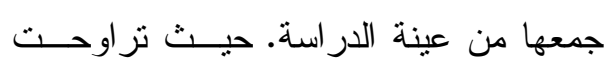

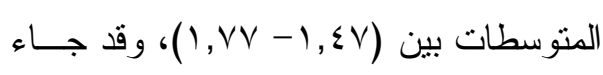

المحور الثاني: المهارات اللغوية فى المرتبة الأولى من حيث درجة تو افره لدى الطالبات، حيث بلغ متوسطه الحسابي (l,VV) وكــان بدرجة نو افر منوسطة، في حين جاء المحور الأول: المهار ات المعرفية في المرتبة الثانية

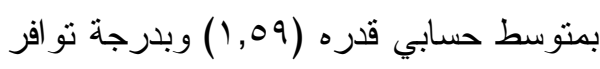

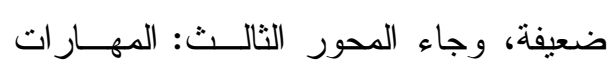

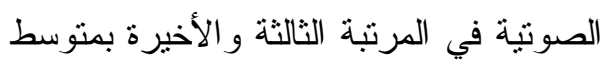

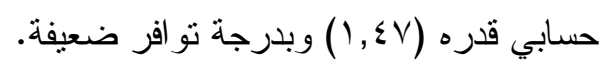

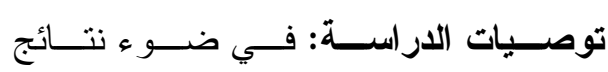
الدر اسة، يوصي الباحثان بما يلي: توصنيات لاتئ

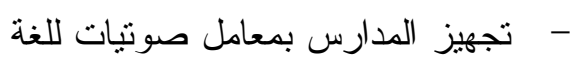
الإنجليزية حيث يتم فيها ممارسة اللغة
ما نادت به در اســة (Xiaohong, 1994) و التي أظهرت نتائجها عن قدرة الطلاب في درد

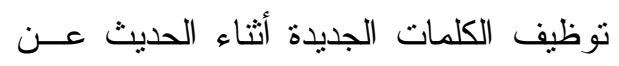
طريق لعبة التخمين ووصف الكلمات و التــي

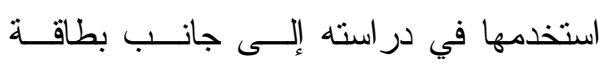
الملاحظة لتقييم أداء الطلاب.

كما وأنه من المستحسن أن يتم شرح

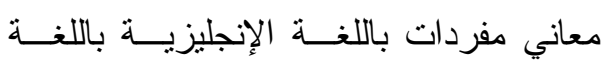

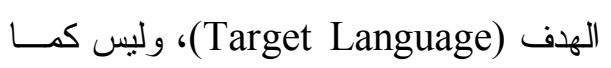
هو ملاحظ من غالبية المعلمات، حيث يـنتم شرح معاني المفردات الجديــدة باللغـــة الأم (Mother Language)

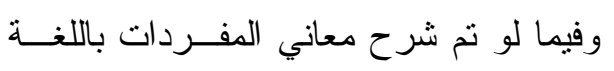
الإنجليزية فإن ذلك سيزيد من رصيد الطالبة اللغوي وسيكون إضافة لقاموسها الخاص. و أما ما يختص بالقو اعد النحوية، فمن

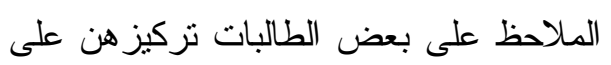

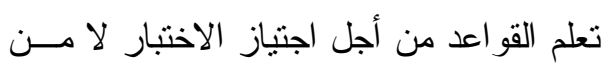

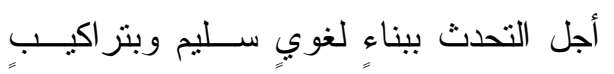

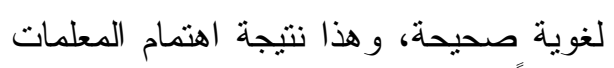

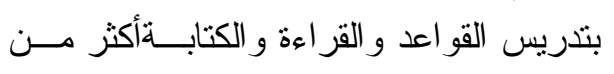
اهتمامهن بتتمية مهار ات الاستماع و التحدث.

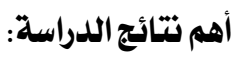
توصــلت الدر اســـة لإعـــداد قائــــة بمهار ات التحدث باللغة الإنجليزية مكونة من

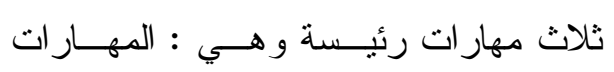

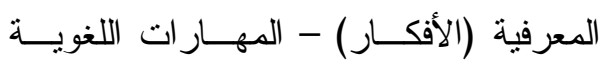




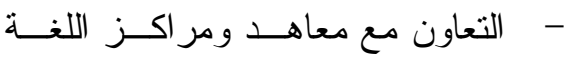

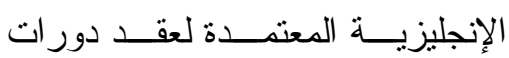

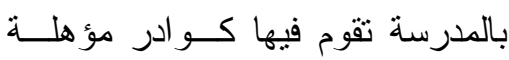

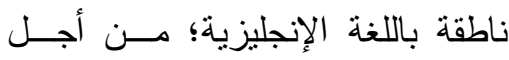

تتمية مهار ات الاتصال الثفهي.

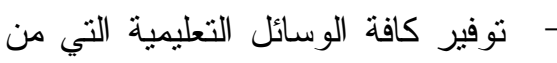

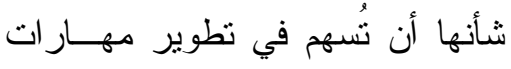

التحدث لدى الطلاب.

عقد دور ات تدريبية للمعلمين لتتميــة

$$
\text { مهار ات الاتصال الثفهي لديهم. }
$$

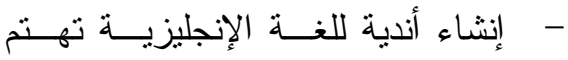

بتطوير مهار ات اللغة داخل أســـوار

$$
\text { المدرسة. }
$$

- تشجيع الطلاب للإسبهام و المـشاركة

في برامج الإذاعة المدرســية التـي لئي

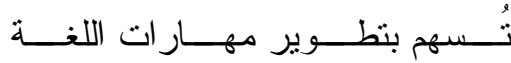

الإنجليزية.

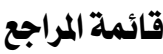

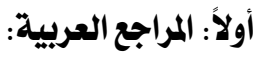

آل ريبة، محمد (V) . . rم).دراسة تقويميــة

لأساليب تـــريس مهـــارات الاتـصـال

الثفوي لاى معلمي اللغة الإنجليزيــة

بالمرحلة الثانوية بمنطقة عسير • رسالة

ماجستير غير منشورة، كليــة التربيــة،

جامعة الملك خالد: أبها.

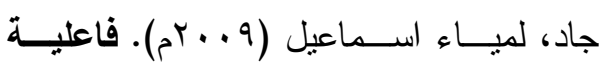
استخدام برنامج كمبيوتر فـي تنميـة
- - إدراج مقررات تهتم بتتمية مهـار ات

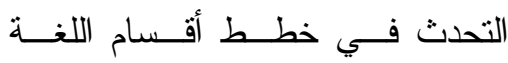

الإنجليزية في الجامعات.

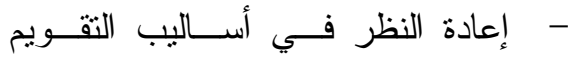

لمهار ات التحدث و الاستماع، وتوزيع

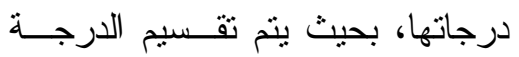

التحصيلية لمادة اللغة الإنجليزية إلـى لـى لـئ

قسمين متساويين شــفوي وتحريــري

بو اقع •م درجة لكل قسم.

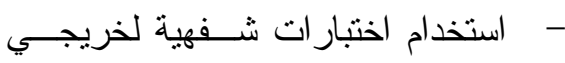

أقسام اللغة الإنجليزية كشرط للالتحاق

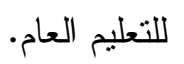

عقد دورات تدريبية فصلية في الدول

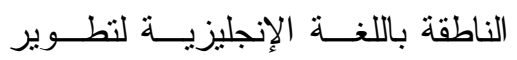
قدر ات الطلاب اللغوية. فرص استخدام الطلاب للغة خـارج أسوار المدرسة. - تضمين المقررات لأنـشطة لغويــة

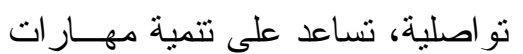
الاتصال الثفهي. - تخصيص حصص در اسـية ضــمن

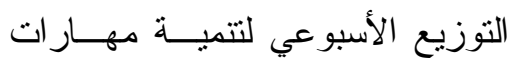
الاتصال الثفوي. - عقد لقاءات دورية مع الطلاب و أولياء أمور هم؛ بهدف زيادة الوعي بأهميــة تعلم مهار ات اللغة. 
الاستماع والتحدث في اللغة الإجليزية

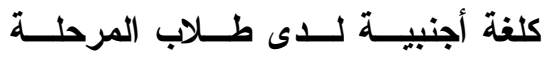

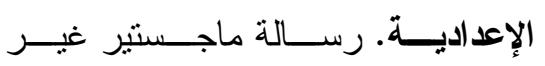
منشورة، كلية التزبية، جامعة المنوفية.

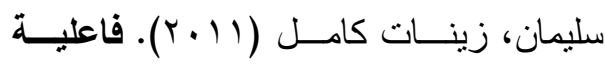
برنامج مقترح قـائم علــى المـــخل التواصلي في تنمية بعـض مهــار ات

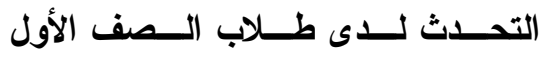
الإعـــدادي.رســـالة ماجـستير غيــر منشورة، قسم المناهج وطرق التدريس، كلية التربية، جامعة بني سويف.

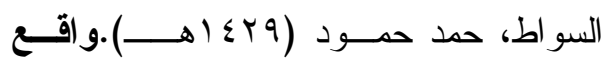
ممارسة مسشرفي اللغــة الإنجليزيــة للإثر اف العيادي من وجهة نظر معلمي

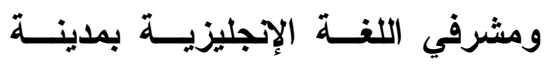
الطائف. رسالة ماجستير غير منشورة. كلية التربية. جامعة أم القــرى: مكـــة مئة المكر مة.

شرف، عزت (ب9 (19).مناثــط المقــدرة التخاطبية في تعليم اللغــة الإنجليزيــة بالمرحلة الثاتوية. رسالة ماجستير غير منشورة، كلية التربية، جامعة أم القرى:

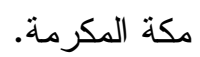

الصلاحي، حسين محمد (^ . - rم). فاعليــة

أسلوب التعلم البنائي في تنمية مهـــارة

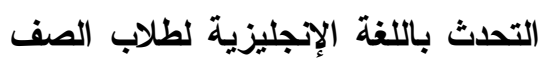

مهارات التحدث باللغة الإنجليزية فــي المرحلة الثانوية.رسالة ماجستير غيــر بالتهر

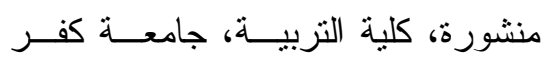
الثيخ.

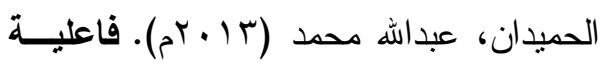
استخدام المهمات التعليمية في تطـــوير مهارات التحدث لاى طلاب مقرر اللغة

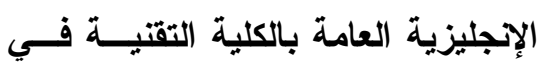

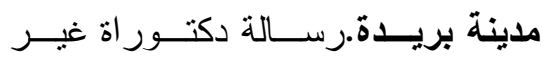
منشورة، قسم المناهج وطرق التدريس، جامعة الملك سعود.

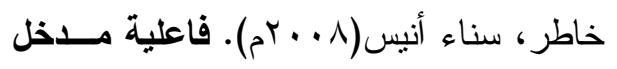

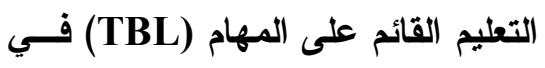

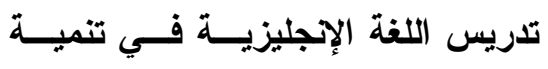

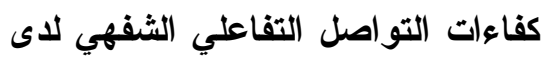
طلاب الصف الأول الثـانوي. رســالة

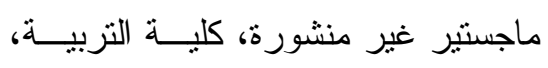
جامعة الزقازيق.

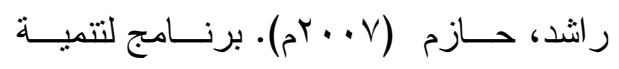

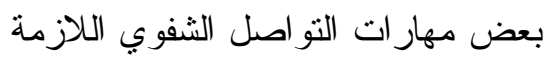

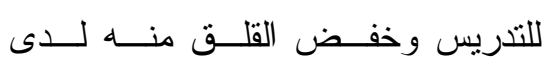

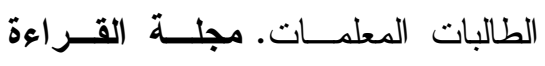

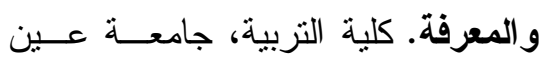

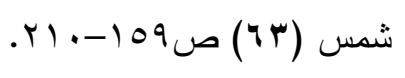

السامولي، شيماء محمد (V) . . r م). فاعليـة السرد القصصي في تنميــة مهــارتي 


$$
\begin{aligned}
& \text { الهلالي، عطية (1) + (Y). واقــع الاتـــال } \\
& \text { اللغوي الثفهي فــي التــدريس بــين } \\
& \text { معلمي اللفة الإجليزية وطلاب المرحلة }
\end{aligned}
$$

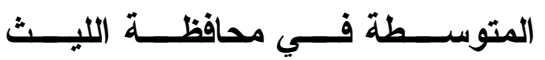

$$
\begin{aligned}
& \text { التعليمية.رسالة ماجستير غير منشورة، }
\end{aligned}
$$

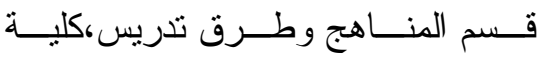

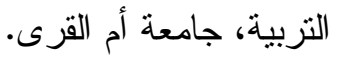

$$
\begin{aligned}
& \text { ثانياً: المراجع الأجنبية: }
\end{aligned}
$$

Abu-Ghararah, A. H. (1992).

"English Foreign Language

Speaking Inability. Its Cases and Remedies". King AbdulAziz University, Vol. 5, Educe. Sic. Jeddah.

Al-Alili, S. (2009). The Effect of Activating Background Knowledge on the Listening Comprehension of Arabic Speaking EFL Learners. (Master thesis, Michigan State University, Michigan, United States, 2009).

Al- Dabbous, J.M. (2002). Acquisition of English for Specific Purposes (ESP) Vocabulary in Arabic Contexts : The Delimitations of Attrition, Journal of Educational and Psychological Sciences (7), retrieved 17-91436 from http://www.jeps.uab.edu.bh/En glish-pdf/3-4.pfd.

$$
\begin{aligned}
& \text { الأول المتوسط. رسالة ماجستير غيــر } \\
& \text { منشورة، كلية التربية، جامعة أم القرى: }
\end{aligned}
$$

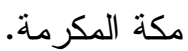

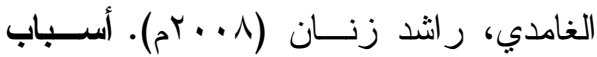

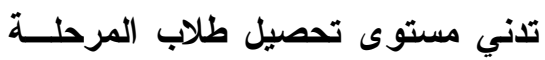

$$
\begin{aligned}
& \text { المتوسطة في تعلم اللغة الإنجليزية من } \\
& \text { وجهة نظـــر الأكــاديميين والمعلمــين } \\
& \text { و المــشرفين فـــي مكـــة المكرمــــة } \\
& \text { و الطائف.رسالة ماجستير غير منشورة، } \\
& \text { جامعة أم القرى: مكة المكرمة. } \\
& \text { كمال الدين، محمد عبد الحميـــ (• ( •Yم). } \\
& \text { أثر برنامج إثرائي قائم علــى التعلــيم } \\
& \text { المتمركز حول الطالب في تنمية بعض برن } \\
& \text { مهارات الاستماع والتحلث في اللغــة } \\
& \text { الإنجليزية لدى طــلاب الــصف الأول } \\
& \text { الثانوي. رسالة ماجستير غير منشورة، } \\
& \text { قسم المنـــاهج وطــرق التذريس،كليــة } \\
& \text { التزبية، جامعة بني سويف. } \\
& \text { مجلي، علي محدد (^ . . rم). تلريس اللغة } \\
& \text { الإنجليزية باستخدام الأنشطة القائمــة }
\end{aligned}
$$

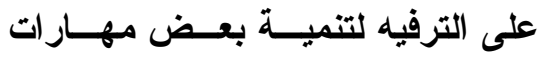

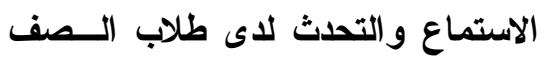

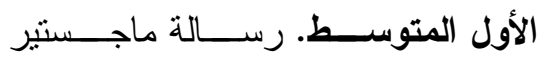

$$
\begin{aligned}
& \text { منشورة، قسم المناهج وطرق التذريس، } \\
& \text { كلية التزبية، جامعة الملك خالد. }
\end{aligned}
$$


\begin{tabular}{lrr} 
to Teach & it ? & Teacher \\
Classroom & Guides. ERIC \\
Document & \multicolumn{2}{c}{ Reproduction }
\end{tabular}

Service. No. ED 433722.

Csabay, N. (2006). Using Comic

Strips in Language Classes.

English Teaching Form, 44(6), $24-26$.

ElFatihi, M. (2005). The Role of Nonverbal Communication in Beginners' EFL Classrooms. Sale' Junior High Schools as a Case.(Master Thesis. Sidi Mohammed Bin Adbullah University,2005).

Farooqui, Sabrin, (2006). developing speaking skills of adult hearners in private universities in Bangladesh : problems and solution Austraion Journal of adult learning Vol47, N.1, P.a5-110. April 2007.

Goan, Felicia. (2001). A Study of Oral and Written Expression Abilities of an Adolescents with Learning Dsiabilities. (Master Thesis, Faculty of Education \& Psychology of Toronto College, New York,2001).

Harris ，D. P. (1996). Teaching English as a Second language. New York, Mc Graw- Hill.

Hughes, M. (1994). The Oral Language of Young Children. New York. Mind Garden.

Lazaraton, A. (2001). Teaching Oral Skills. In Celce-Murica,
Al-Gaeed, I. H. (2000). An Investigation Study of the English as a Foreign Language Teacher Preparation Programs of Saudi Arabia as Perceived by Programs Students and Graduates. (Unpublished Doctorate dissertation, University of Indiana,2000).Journal of Research in Education and Psychology, Vol. 14, No. 1, pp 2-27.

Al Khouli, M , Ali.(2002). Teaching English To Arab Students. Amman , Al - Falah House , $4^{\text {th }}$ ed.

Al mutawa, N. \& Kailani, T. (1994).Methods of teaching English to Arab students. Hong Kong: Longman.

Al-Subhi, A. (1992). "Students Assessments in English Language in Saudi Arabia Schools: Present Status and Suggested Improvements". King Abdul-Aziz University, Vol.5, Educe. Sic. Jeddah.

Buhler, H. (2000). Communication Strategies in a First-Grade Classroom: A Collaborative Teaching Curriculum-Based Approach.(Doctoral Dissertation.

Fordham University,2000).

Burkat, G. (1998). Spoken Language: What it is and How 
Palmerston North, New
Zealand, 2008).

Smith, Z. (1998). Building Classroom Community through Group Assignments, Role Plays and Modeling. Paper Presented at the Annual Meeting of the American Political Science Association.

Weide, R. (1995). Oral Communication in High School. (Master Thesis, Grand Vally State University,1995).

Wilson, J. (1997). A Program to Develop the Listening and Speaking Skills of Children in a First Grade Classroom. Research Reports.

Xiaohong, D. (1999). Developing Oral Communication Competence among English Majors at Intermediate Level. FORUM, a Journal for the Teacher of English Outside the United States, (32). PP31-32.
M. (Ed.). Teaching English as a Second or Foreign Language. (pp. 103 - 115). USA : Heinle $\&$ Heinle.

Mixon, M. and Temu, P. (2006). First Road to Learning Language through Stories, English Teaching Forum, 44 (3), $14-19$.

Ozsevik, Z. (2010). The use of Communicative Language Teaching (CLT): Turkish EFL Teachers' Perceived Difficulties in Implementing CLT in Turkey. (Doctoral dissertation, University of Illinois at UrbanaChampaign,United States,2010).

Rapley, D. J. (2008). Policy and reality: the teaching of oral communication by Japanese teachers of English in public junior high schools in Kurashiki City, Japan. (Master Thesis, Massey University, 